\title{
THE EFFECT OF ANTHROPOGENIC CHANGE IN THE STRUCTURE OF DIATOMS AND WATER QUALITY OF THE ŻOŁYNIANKA AND JAGIELNIA STREAMS
}

\author{
Łukasz Peszek', Teresa Noga' ${ }^{2}$, Jadwiga Stanek-Tarkowska ${ }^{3}$, Anita Pajączek ${ }^{3}$, \\ Natalia Kochman-Kędziora', Marcin Pieniążek ${ }^{3}$
}

1 Department of Agroecology, Faculty of Biology and Agriculture, University of Rzeszów, Ćwiklińskiej 1A, 35-601 Rzeszów, Poland, e-mail: lukaspeszek@gmail.com

2 Department of Biological Foundations of Agriculture and Environmental Education, Faculty of Biology and Agriculture, University of Rzeszów, Zelwerowicza 8B, 35-601 Rzeszów, Poland, e-mail: teresa.noga@interia.pl

${ }^{3}$ Department of Soil Studies, Environmental Chemistry and Hydrology, Faculty of Biology and Agriculture, University of Rzeszów, Zelwerowicza 8B, 35-601 Rzeszów, Poland

Received: 2014.10.30

Accepted: 2015.02.04 Published: 2015.04.01

\begin{abstract}
The studies on bentic diatoms were conducted in 2009-2011 at eight samplings sites over the Żołynianka stream and its tributary, the Jagielnia. 427 diatom taxa were recorded in total. Achnanthidium minutissimum var. minutissimum, Aulacoseira ambigua, Fragilaria capucina var. capucina, Gomphonema parvlum, Navicula gregaria, Nitzschia palea and Planothidium lanceolatum were dominant taxa in both watercourses. Chemical analysis of water showed high chemical status of water at most of sampling sites. The results of diatomaceous analysis conducted with OMNIDIA software revealed moderate and poor condition of water. The best water quality was recorded in the Jagielnia stream (good or moderate status). The values of the analyzed indices showed the worst water quality on the Żołynianka at site four, showing bad ecological status. TDI index deviated the most from the other two indices (IPS and GDI), always indicating poorer water quality.
\end{abstract}

Keywords: ecological status, diatoms Bacillariophyceae, diversity, indiced IPS, GDI, TDI, flowing waters.

\section{INTRODUCTION}

The use of diatoms as indicators (bioindicators) of water quality in flowing and lentic ecosystems, fossil and extreme environments, and reading climate changes begun in 1970's. Due to high correlation with physicochemical parameters of water, diatomaceous indices are widely used for monitoring all over the world and in Europe [Descy, Coste 1991, Prygiel, Coste 1993, 1999, Whitton, Rott 1996, Kwandrans et al. 1998, Prygiel et al. 1998, Stroemer, Smol, 2004, 2010].

Thanks to a short life cycle, diatoms can respond quickly to changes in the environment. Many species have specific, narrow ecological scale dependent on numerous habitat factors. Species composition and the abundance of dia- toms reflects the state of aquatic environment in which they live, what makes them excellent indicators of the quality of surface waters [Denys 1991, Kawecka, Eloranta 1994, Coring 1996].

Algological studies have not been conducted on the territory of the Podkarpacie Province, with the exception of the upper and the middle sections of the San River, in which the diatom Didymosphenia geminata developed massively in the 90's [Kawecka, Sanecki 2003]. Over the past few years studies have been carried out on diatom diversity [Noga, Siry 2010, Tambor, Noga 2011, Noga 2012, Bernat, Noga 2012, Noga et al. 2012, Pajączek et al. 2012, Noga et al. 2013a, 2014a,b] and research making use of the role of diatoms as an indicator to evaluate water quality [Noga et al. 2013 b,c,d]. 
Preliminary information on the richness of diatom species in the Żołynianka and the Jagielnia streams, occurrence of endangered and rare species and new taxa to Poland were presented in two scientific papers [Noga et al. 2014 a,b].

The aim of this study was to evaluate water quality of the Żołynianka and the Jagielnia streams based on the diatom assemblages analysis and diatomaceous indices values calculated with Omnidia software.

\section{STUDY AREA}

The study was conducted over the Żołynianka and the Jagielnia (right tributary of the Żołynianka) streams, which flow from the North to the South in the area of Łańcut district, in the Podkarpacie province. According to Kondracki [2009], the studied area is located within two mesoregions - the southeastern part of Kolbuszowa Plateau (Płaskowyż Kolbuszowski) and the northern part of Subcarpathian Proglacial Valley (Pradolina Podkarpac$\mathrm{ka}$ ), the Carpathian and Podkarpackie province and the macroregion of Sandomierz valley.

The Żołynianka stream (left-bank tributary of the Wisłok River) is a $10.8 \mathrm{~km}$ long stream, with 37.7 $\mathrm{km}^{2}$ of basin area and drop rate from 0.7 to $10 \%$. The stream valley is composed of sand and aeolian sands.
The "Tama" reservoir used for fish farming is located at the place where the Żolynianka and the Jagielnia connect. The "Rajszula" reservoir with an area of 4.25 ha was built on the Jagielnia, it performs similar functions as the Tama. On the Żołynianka there are also several smaller fish ponds, starting from the spring area and along the stream. The catchments of both streams are mostly of agricultural character [Michalczyk 1988, Lach, Wnuk 1998].

Studies were conducted at eight sampling sites in the period from June 2009 to May 2011 on the Żołynianka stream (sampling sites 1-5) and its tributary, the Jagielnia (sampling sites 6-8) (Figure 1). The sampling site number 5 is the only one to be located on the area of Białobrzegi village, the rest of them are located in Żołynia village.

\section{MATERIALS AND METHODS}

Materials for the studies were collected in 2009-2011 on the Żołynianka stream (five sampling sites) and its tributary the Jagielnia (three sampling sites) from all available habitats (stones, sand, slit, aquatic macrophytes). $\mathrm{pH}$, conductivity and water temperature were measured at each site. Chemical analysis of the water was carried out in the Departmental Laboratory of Analysis of Environment Health and Materials of Agricultural

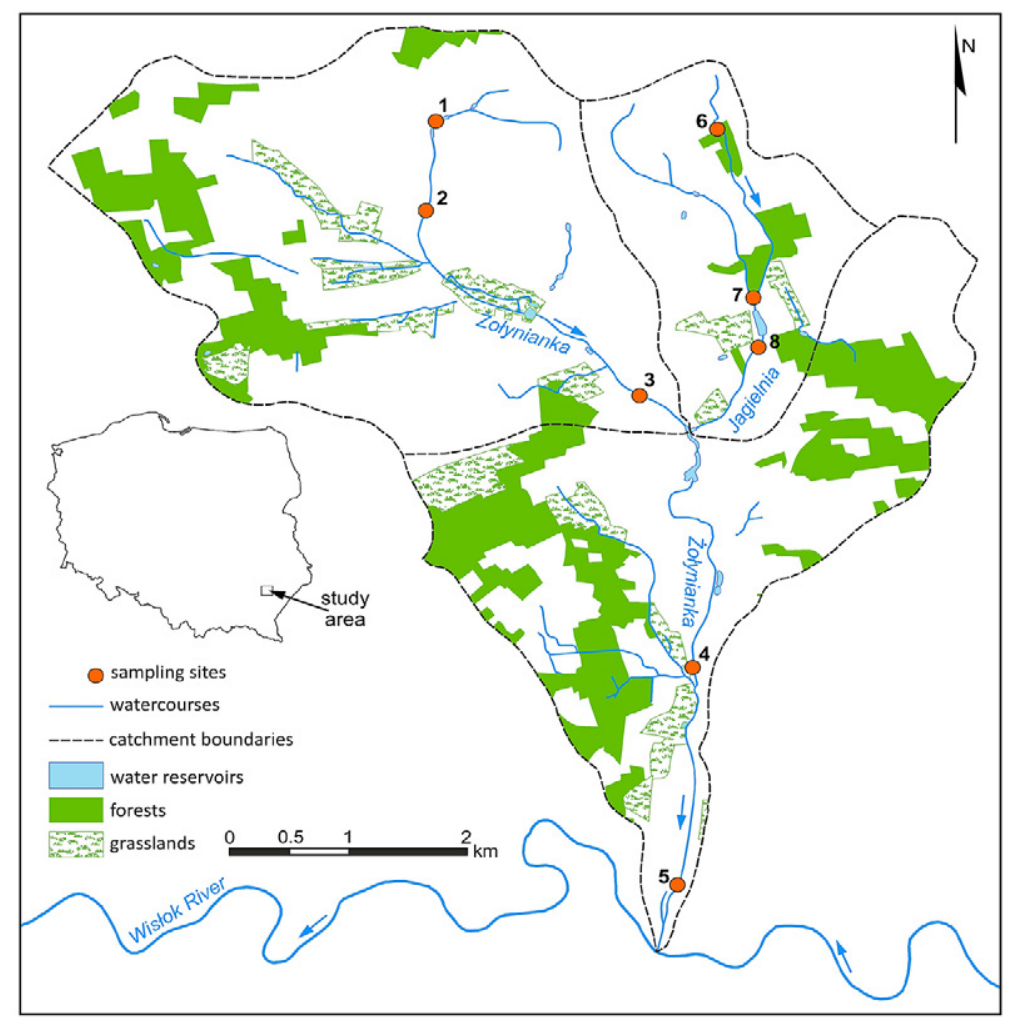

Figure 1. Location of the study sites 
Origin by means of a liquid chromatography apparatus - PeakNet Dionex 2001-2006, version 6.80.

To obtain pure diatom valves a part of each sample has been subjected to maceration in sulfochromic mixture (mixture of concentrated sulfuric acid and chromic acid in proportion 3:1), then washed in a centrifuge (at $2500 \mathrm{rpm}$ ). The diatoms were mounted in permanent diatom slides with synthetic resin - Pleurax (refractive index 1.75). The material was prepared according to the methods applied by Kawecka [2012].

Diatoms were identified and counted under a Nikon ECLIPSE 80i light microscope (LM) under $1000 \times$ magnification, equipped with Plan Apochromatic objective $\times 100$ for oil immersion (NA 1.4) and differential interference contrast (DIC). For Scanning Electron Microscope (SEM) observations samples were coated at Turbo-Pumped Sputter Coater Quorum Q 150OT ES with a 20nm layer of gold and observed under a Hitachi SU 8010 microscope. The identification was supported by the following references: Krammer, Lange-Bertalot [1986-1991], Lange-Bertalot [1993, 2001], Krammer [2000, 2002, 2003], Rumrich et al. [2000], Werum, Lange-Bertalot [2004], Levkov [2009], Hofmann et al. [2011].

Species composition in the collected samples was determined by counting specimens on randomly selected transects under light microscope. The number of valves counted was 400 . Species with a content of $5 \%$ or above in a given diatom assemblage were defined as dominant.

Omnidia softwere [Lecointe et al. 1993] version 4.2, was used to calculate diatomaceus indices, including ecological and taxonomic data [Prygiel \& Coste 1993].

Analysis of the diatom communities structure was conducted to determine the ecological status of the Żołynianka and the Jagielnia streams. The results of these analyses were presented applying chosen diatomaceous indices (Table 1), for which the range of ecological classes of water quality and the ecological status has been adopted according to Dumnicka et al. [2006]. Indices of organic pollution:
- IPS - Specific Pollution Sensitivity Index [Coste in CEMAGREF 1982], based on species,

- GDI - Generic Diatom Index [Coste, Ayphassorho 1991], based on genera. The indices are scaled from 1 to 20 (when water quality increases there is an increase of the value of the indicator).

- TDI - Trophic Diatom Index [Kelly, Whitton 1995], which is scaled from 1 to 100 (the higher the value, the higher trophic state of water).

The percentage of participation of species characteristic for organic pollution (PT) must be taken into account in the interpretation of the TDI index. There is a possibility of organic pollution if the values of PT are above $20 \%$.

Species diversity in diatom assemblages was determined using Shannon-Wiener (H') indicator:

$$
\mathrm{H}^{\prime}=\sum_{i=1}^{s}\left(\frac{\mathrm{n}_{1}}{\mathrm{n}} \log _{2} \frac{\mathrm{n}_{1}}{\mathrm{n}}\right)
$$

where: $n_{i}$ - number of individual diatoms of the $i$ species,

$n$ - total number of individual counts

( $n / n$ - relative abundance of the $i$ species),

$s$ - total number of diatom taxa which occurred in the sampling site.

Based on Siemińska et. al. [2006] the Red List of Algae created for Poland, species at varying degrees of threat were distinguished (Ex - Extinct or probably extinct, E - Endangered, V - Vulnerable, $\mathrm{R}$ - Rare, I - Indeterminate).

\section{RESULTS}

Waters of the studied streams were characterized by a $\mathrm{pH}$ reaction which was near neutral or alkaline. The lowest $\mathrm{pH}$ values (6.5) were recorded on the spring section of the Jagielnia stream. The highest $\mathrm{pH}$ (8.2) was recorded in winter at the site number five over the Żołynianka stream. Electrolytic conductivity values ranged from 158 to 435 $\mu \mathrm{S} / \mathrm{cm}$ and reached the highest values in the lower reaches of the Żołynianka. In spring 2011, chemi-

Table 1. The range of indices value and corresponding ecological status according to Dumnicka et al. [2006]

\begin{tabular}{|c|c|c|c|c|c|}
\hline Water Quality Class* & Ecological state & IPS & GDI & TDI & Trophic state \\
\hline I & high & $>17$ & $>17$ & oligotrophic \\
\hline II & good & $15-17$ & $14-17$ & $35-50$ & oligo/mesotrophic \\
\hline III & moderate & $12-15$ & $11-14$ & $50-60$ & mesotrophic \\
\hline IV & poor & $8-12$ & $8-11$ & $60-75$ & eutrophic \\
\hline V & bad & $<8$ & $<8$ & $>75$ & hypertrophic \\
\hline
\end{tabular}

* According to the Decree of the Minister of the Environment from 9 Nov. 2011 (Dz. U. No 257, pos. 1545). 
cal analysis of water was also performed. Most of the studied water parameters indicated a high chemical status. The largest deviation from the standards of quality corresponding to the high status were observed for nitrates at the site two (6.066 $\left.\mathrm{mg} \mathrm{NO}_{3} / \mathrm{l}\right)$ and at the site six (14.224 $\left.\mathrm{mg} \mathrm{NO}_{3} / \mathrm{l}\right)$, indicating a chemical status below good (Table 2,3).

427 diatom taxa were recorded in the Żołynianka and the Jagielnia streams in total (see list of diatom taxa). The greatest species diversity occurred at the site number three at which 244 taxa were found. The smallest number of diatom taxa (94) was recorded at the site number six in the upper reaches of the Jagielnia (see list of diatom taxa). The greatest abundance of diatom taxa were recorded from genera: Pinnularia (49), Navicula (41), Nitzschia (40), Fragilaria (34) and Gomphonema (27).
Shannon-Wiener (H') species diversity index was calculated for all sampling sites, its high values ranged from 4.2 at the site number four to 7.2 at the site number three (Table 2).

Forty diatom taxa were classified as dominant i.e. their number at the sampling site was higher or equal to 5\%. In the Żołynianka stream twenty-seven taxa were recorded as dominant, twenty in the Jagielnia. Seven taxa reached the rank of dominants in both streams and they were as follows: Achnanthidium minutissimum var. minutissimum, Aulacoseira ambigua, Fragilaria capucina var. capucina, Gomphonema parvlum, Navicula gregaria, Nitzschia palea and Planothidium lanceolatum. The most frequent dominant taxa in the Żołynianka stream were: Aulacoseira distans, Navicula lanceolata and Nitzschia fonticola. In the Jagielnia the most com-

Table 2. Values of temperature (T), pH, conductivity $(\mathrm{C})$ and Shannon-Wiener $\left(\mathrm{H}^{\prime}\right)$ species diversity index at studies sites

\begin{tabular}{|c|c|c|c|c|c|}
\hline Site & Date & $\mathrm{T}\left[{ }^{\circ} \mathrm{C}\right]$ & $\mathrm{pH}$ & $\mathrm{C}[\mu \mathrm{S} / \mathrm{cm}]$ & $\mathrm{H}^{\prime}$ \\
\hline \multirow{4}{*}{1} & 07.2009 & 20 & 7.1 & 235 & 5.15 \\
\hline & 10.2009 & 10.5 & 6.8 & 275 & 5.94 \\
\hline & 02.2010 & 0.3 & 7.2 & 250 & 5.86 \\
\hline & 05. 2011 & 15.7 & 6.8 & 227 & 5.96 \\
\hline \multirow{4}{*}{2} & 07.2009 & 20 & 7.1 & 265 & 6.15 \\
\hline & 10.2009 & 10 & 6.8 & 320 & 5.81 \\
\hline & 02.2010 & - & - & - & - \\
\hline & 05. 2011 & 15.8 & 6.8 & 258 & 6.22 \\
\hline \multirow{4}{*}{3} & 07.2009 & 19 & 7.0 & 283 & 5.90 \\
\hline & 10.2009 & 10.3 & 7.0 & 348 & 7.16 \\
\hline & 02.2010 & 0.9 & 7.9 & 342 & 6.45 \\
\hline & 05. 2011 & 13.6 & 6.9 & 297 & 5.88 \\
\hline \multirow{4}{*}{4} & 07.2009 & 18 & 7.1 & 277 & 4.20 \\
\hline & 10.2009 & 10.1 & 7.0 & 344 & 4.68 \\
\hline & 02.2010 & 2.9 & 8.1 & 371 & 4.98 \\
\hline & 05. 2011 & 14.4 & 7.3 & 311 & 4.83 \\
\hline \multirow{4}{*}{5} & 07.2009 & 18 & 7.1 & 279 & 6.17 \\
\hline & 10.2009 & 11 & 7.7 & 362 & 6.11 \\
\hline & 02.2010 & 2.3 & 8.2 & 435 & 5.74 \\
\hline & 05. 2011 & 14 & 7.1 & 309 & 5.74 \\
\hline \multirow{4}{*}{6} & 07.2009 & 17 & 6.5 & 158 & 4.64 \\
\hline & 10.2009 & 10.3 & 6.7 & 335 & 5.05 \\
\hline & 02.2010 & - & - & - & - \\
\hline & 05. 2011 & 14.9 & 6.8 & 245 & 4.67 \\
\hline \multirow{4}{*}{7} & 07.2009 & 23 & 7.1 & 236 & 5.21 \\
\hline & 10.2009 & 10.1 & 7.4 & 369 & 5.29 \\
\hline & 02.2010 & - & - & - & - \\
\hline & 05. 2011 & 15.5 & 6.9 & 319 & 5.56 \\
\hline \multirow{4}{*}{8} & 07.2009 & 16 & 7.0 & 256 & 5.95 \\
\hline & 10.2009 & - & - & - & - \\
\hline & 02.2010 & - & - & - & - \\
\hline & 05. 2011 & 15.7 & 7.2 & 257 & 5.38 \\
\hline
\end{tabular}


Table 3. Chemical water parameters of Żołynianka and Jagielnia streams measured in spring 2011 (chemical status of water according to the Decree of the Minister of the Environment from 9 Nov. 2011, Dz. U. No 257, pos. 1545)

\begin{tabular}{|c|c|c|c|c|}
\hline Site & $\mathrm{mg} \mathrm{Cl}^{-} /$ & $\mathrm{mg} \mathrm{NO}_{2}{ }^{-} /$ & $\mathrm{mg} \mathrm{NO}_{3}{ }^{-} /$ & $\mathrm{mg} \mathrm{SO}_{4}{ }^{2-} /$ \\
\hline 1 & 6,78 & 0,11 & 3,58 & 18,79 \\
\hline 2 & 8,23 & 0,12 & 6,07 & 25,02 \\
\hline 3 & 9,41 & 0,14 & 4,67 & 25,90 \\
\hline 4 & 9,00 & 0,12 & 2,93 & 28,03 \\
\hline 5 & 8,51 & 0,15 & 2,63 & 28,53 \\
\hline 6 & 11,51 & $\mathrm{BQL}$ & 14,22 & 32,48 \\
\hline 8 & 5,96 & $\mathrm{BQL}$ & 1,20 & 19,66 \\
\hline
\end{tabular}

$\mathrm{BQL}$ - below the limit of quantification chemical status of water

$\square$ high $\square$ good $\square$ below good

mon dominats were: Achnanthidium minutissimum var. minutissimum and Planothidium lanceolatum. In all study seasons, the greatest abundance in assemblage reached: Cocconeis placentula var. euglypta $(50.6 \%)$ - in summer at the site four, Navicula tripunctata (29.1\%) in spring and Achnanthidium minutissimum var. minutissimum $(26.7 \%)$ in summer at the site seven (Plate 1-3).

The degree of organic pollution and the amount of nutrients were determined by using the Specific Pollution Sensitivity Index (IPS). The highest values of this index (15.3) were recorded

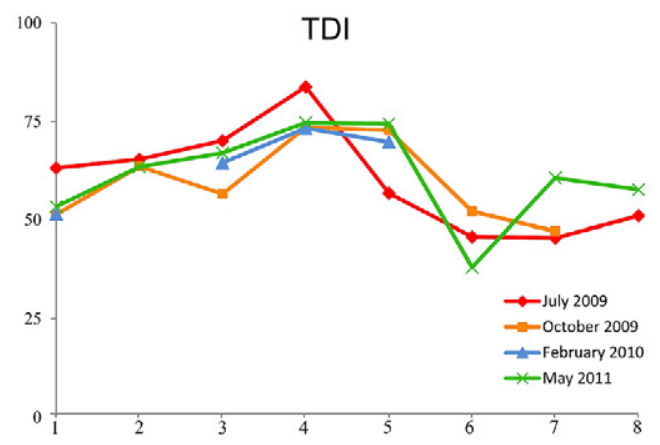

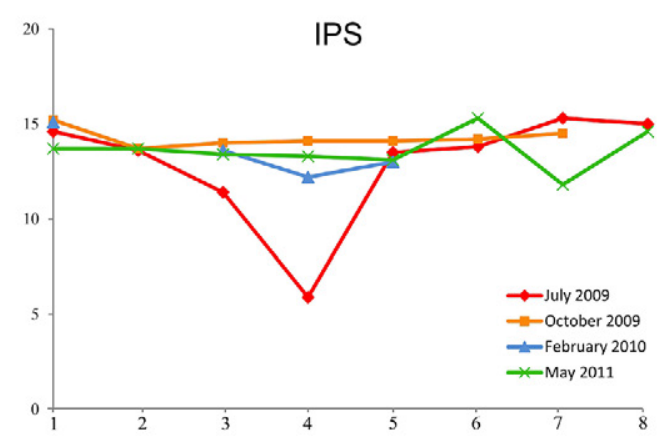

during summer and spring in the Jagielnia stream and in autumn and winter at the spring section of the Żołynianka stream (15.2). The lowest value was recorded in summer at the site four (5.9). The values of Generic Diatom Index (GDI) determining content of organic and inorganic nutrients were the lowest at the site four (from 7.9 in summer to 9.1 in winter). The highest values $(>14)$ of GDI index were noted at the sites six and seven. The assessment of inorganic nutrient concentrations was determined based on the Trophic Diatom Index (TDI), which values ranged from 38.1 in the Jagielnia to 83.8 in the Żołynianka in July at the site four. Along with the TDI index, the occurrence of taxa resistant to organic pollution (\%PT) was analyzed. PT values were low and did not exceed $20 \%$ at most sites. The site number four was an exception, PT index values in all sampling seasons exceed $30 \%$ there, while in the spring season it exceeded even 50\% (Figure 2).

60 diatom taxa from the Polish Red List of Algae were recorded, which constituted 14\% of the total number of identified taxa (see list of diatom taxa, Plate 4, 5).

\section{DISCUSSION}

The Żołynianka stream and its tributary the Jagielnia are small watercourses flowing mainly
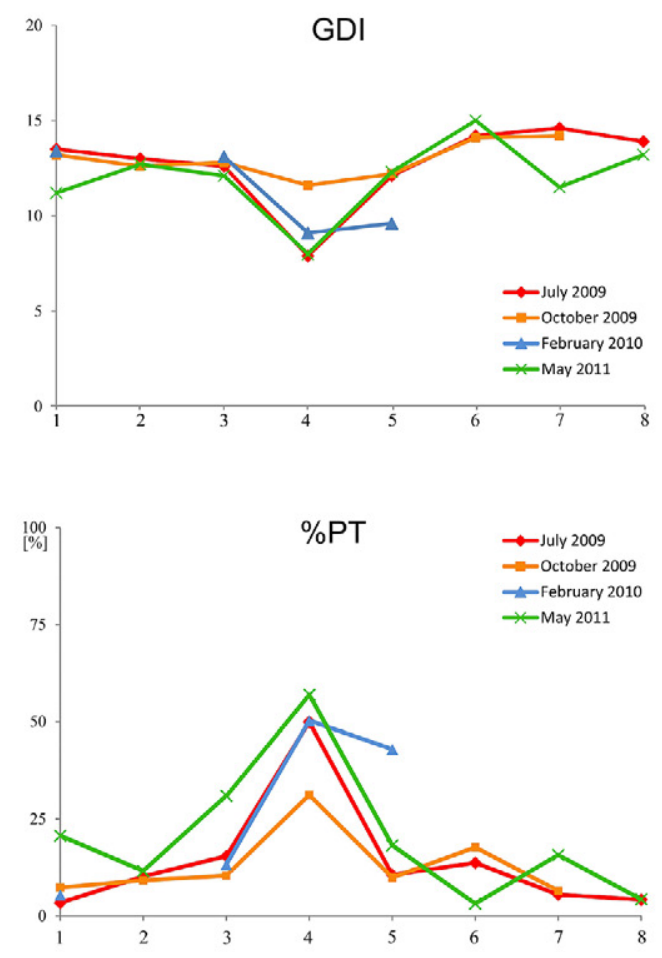

Figure 2. The values of diatomaceus indices GDI, IPS, TDI and \%PT for sites in Żołynianka (1-5) and Jagielnia (6-8) streams in 2009-2011 

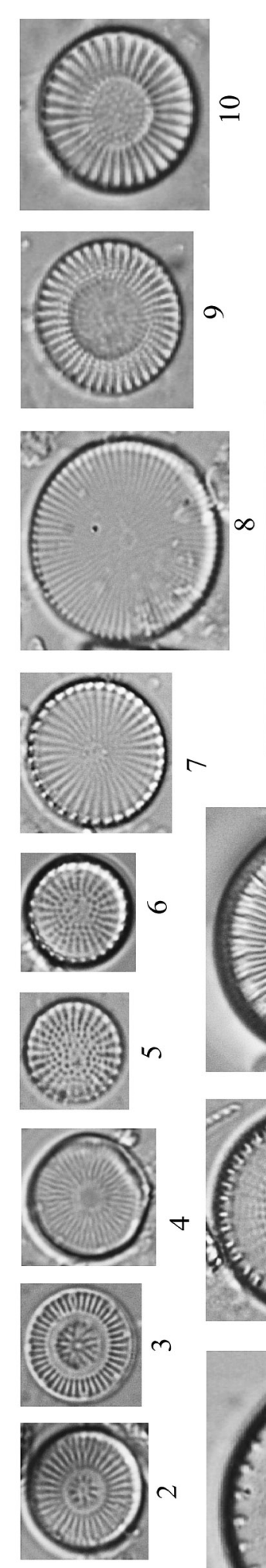

0
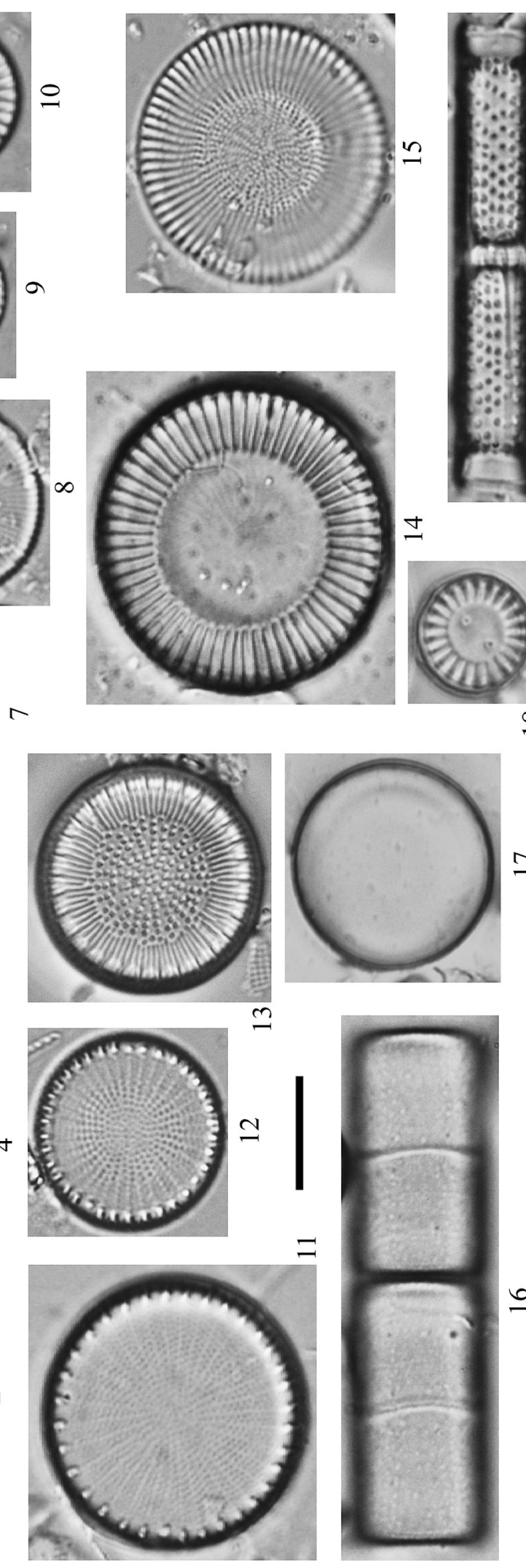

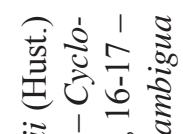

:

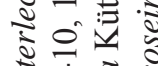

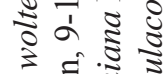

穴

व

: चै है

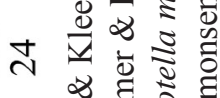

$\because$ 든

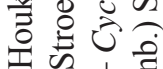

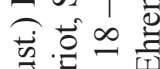

至过焉

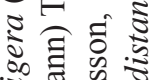

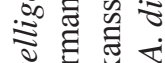

苍票

원 可

为客

응 司

ธै

ดิ

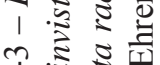

น.

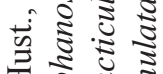

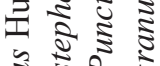

ॠ जू

हิँ
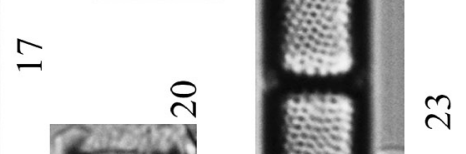

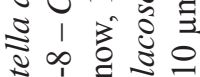

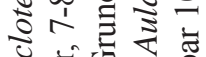

过苛

।

$-\sum_{0} 0$

ॠ

๘

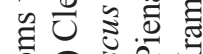

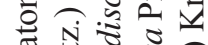

㱐 卷

.

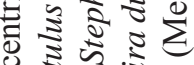

ठ․

है ह 늘

क

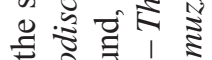

फ्प डิ

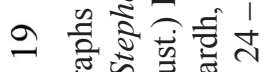

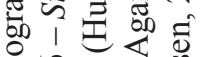

넌

¿ ब

낭

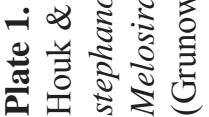




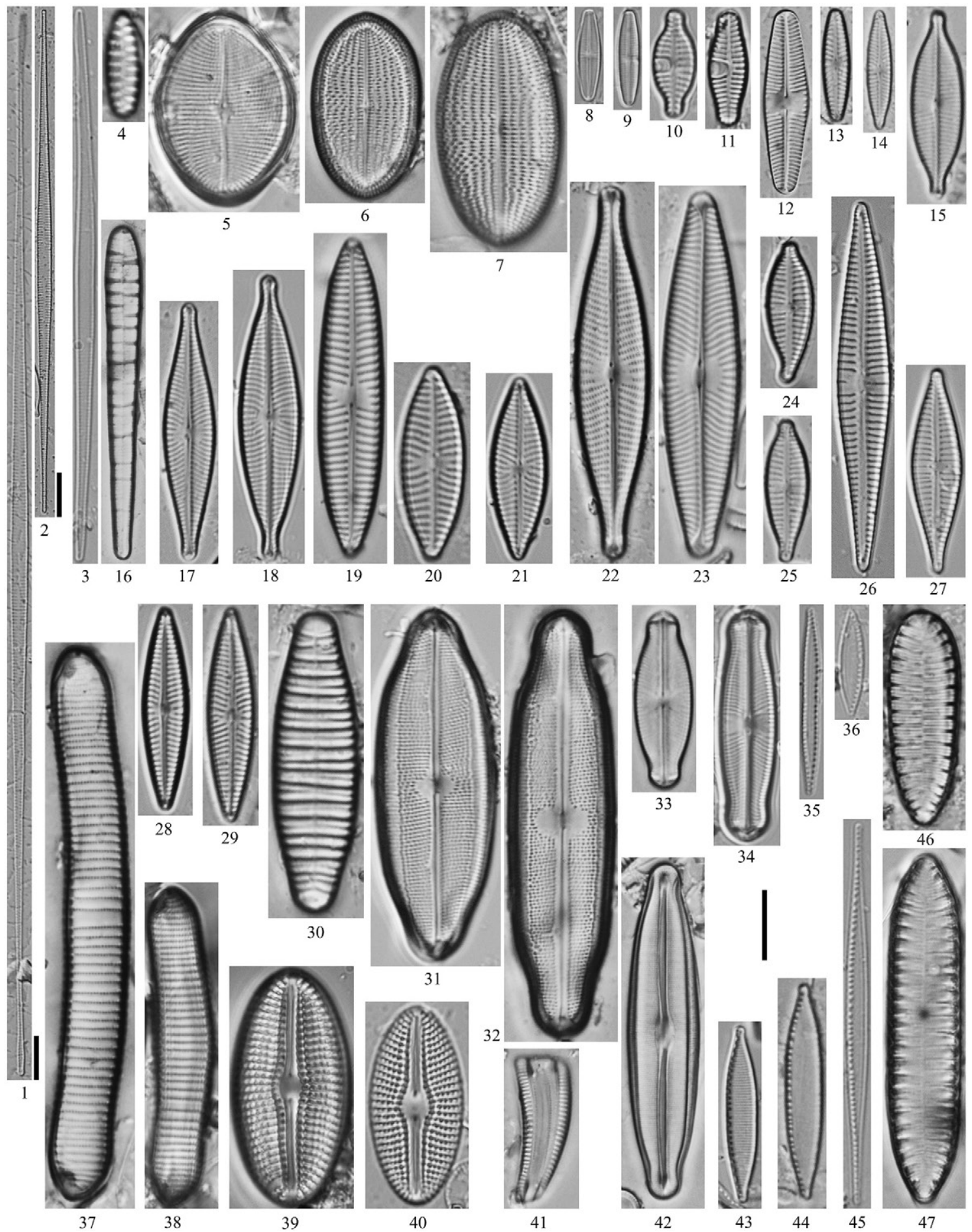

Plate 2. LM micrographs of selected the most numerous diatoms taxa:1-2 - Fragilaria acus (Kütz.) Lange-Bert., 3 - F. nanana Lange-Bert., 4 - F. pinnata Ehrenb., 5 - Cocconeis pediculus Ehrenb., 6-7 - C. placentula var. euglypta Ehrenb., 8-9 - Achnantchidium minutissimum (Kütz.) Czarnecki var. minutissimum, 10-11 - Planothidium frequentissimum (Lange-Bert.) Lange-Bert., 12 - P. lanceolatum (Brébisson) Lange-Bertalot, 13-14 - Navicula tenelloides Hust., 15 - N. gregaria Donkin, 16 - Meridion circulare (Gréville) Agardh var. circulare, 17 - Navicula cryptocephala Kütz., 18 - N. capitatoradiata Germain, 19 - N. tripunctata (O.F. Müller) Bory, 20 - N. upsaliensis (Grunow) Peragallo, 21 - Navicula antonii Lange-Bert., 22 - N. rhynchocephala Kütz., 23 - N. lanceolata (Agardh) Ehrenb., 24-25 - Gomphonema parvulum (Kütz.) Kütz. var. parvulum, 26-27 - G. gracile Ehrenb., 28-29 - N. cryptotenella Lange-Bert., 30 - Diatoma vulgaris Bory, 31-32 - Neidium affine (Ehrenb.) Pfizer, 33-34 - Sellaphora pupula (Kütz.) Mereschkovsky, 35 - Nitzschia archibaldii Lange-Bert., 36 - N. pusilla Grunow, 37-38 - Eunotia formica Ehrenb., 39-40 - Diploneis krammeri Lange-Bert. \& Reichardt, 41 - Rhoicosphenia abbreviata (Agardh) Lange-Bert., 42 Frustulia vulgaris (Thwaites) De Toni, 43 - Nitzschia fonticola (Grunow) Grunow, 44 - N. palea (Kütz.) W. Smith, 45 - N. gracilis Hantzsch, 46 - Surirella minuta Brébisson ex Kütz., 47 - S. angusta Kütz. Scale bars $10 \mu \mathrm{m}$ 

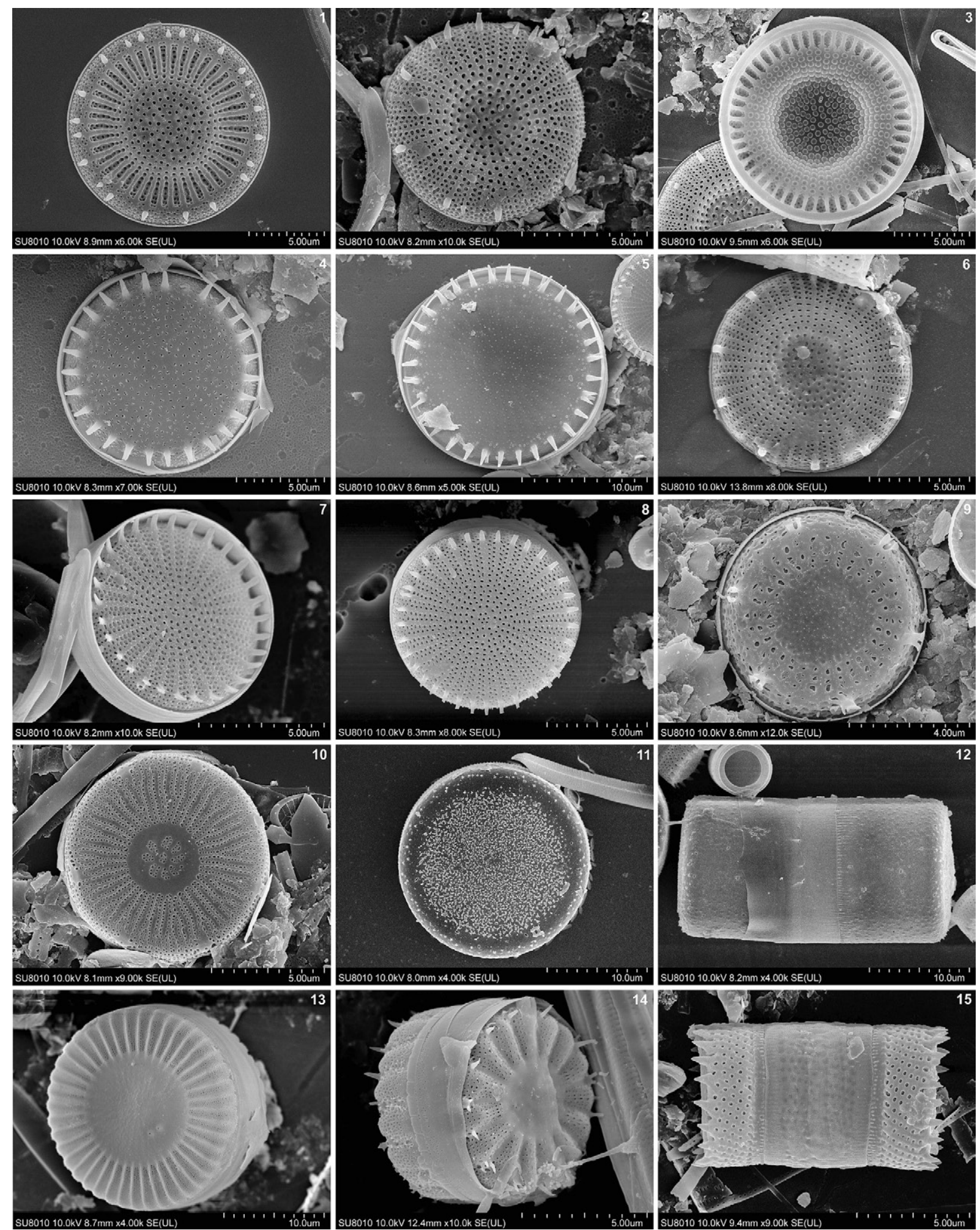

Plate 3. SEM micrographs of the selected centric diatoms taxa: 1-3 - Cyclostephanos dubius (Hust.) Round, 4-5 - Stephanodiscus hantzschii Grunow, 6 - S. minutulus (Kütz.) Cleve \& Möller, 7-8 - Cyclostephanos invistatus (Hohn \& Hellermann) Theriot, Stroermer \& Håkasson, 9-10 - Discostella pseudostelligera (Hust.) Houk \& Klee, 11-12 - Melosira varians Agardh, 13-14 - Cyclotella meneghiniana Kütz., 15 - Aulacoseira distans (Ehrenb.) Simonsen 

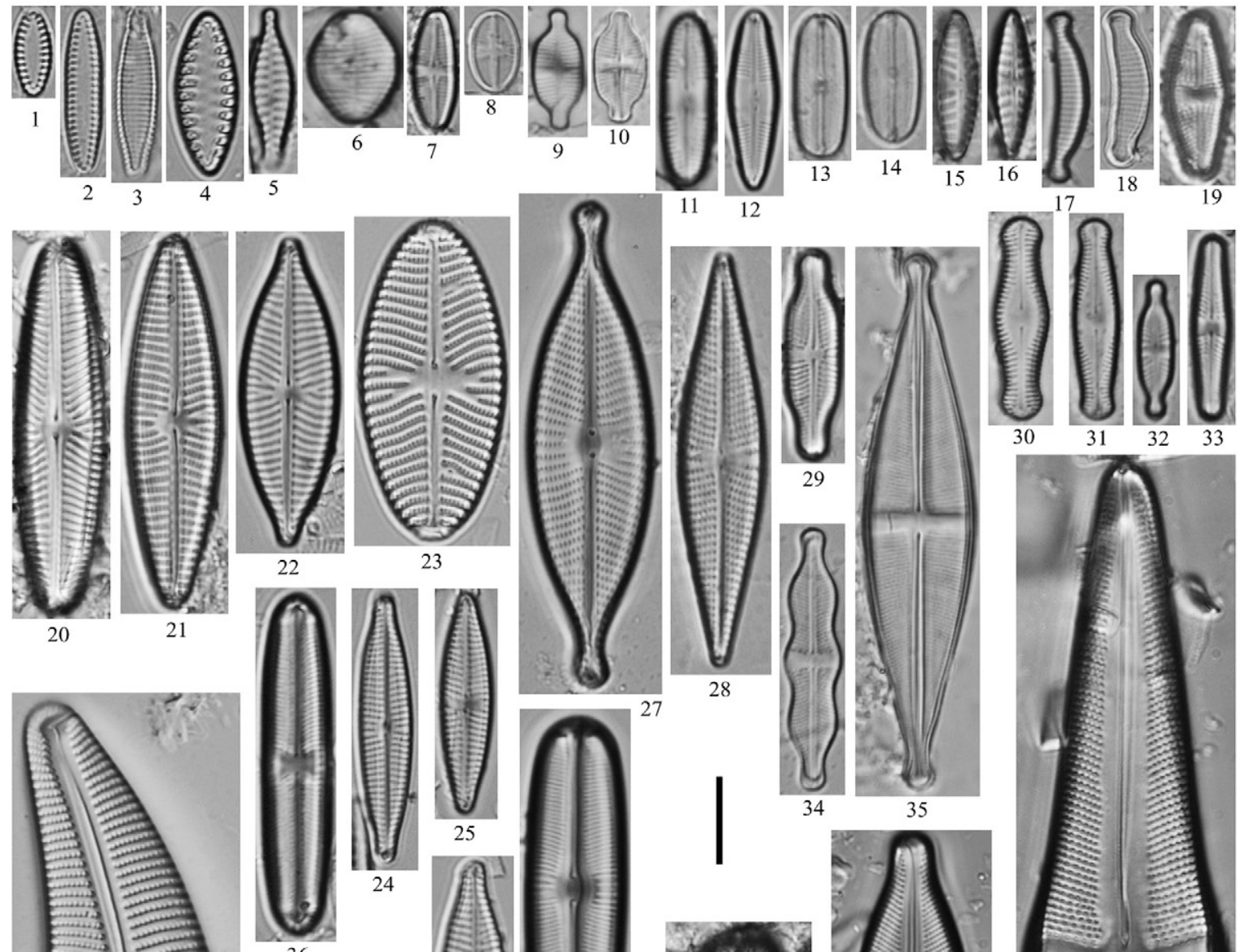

23

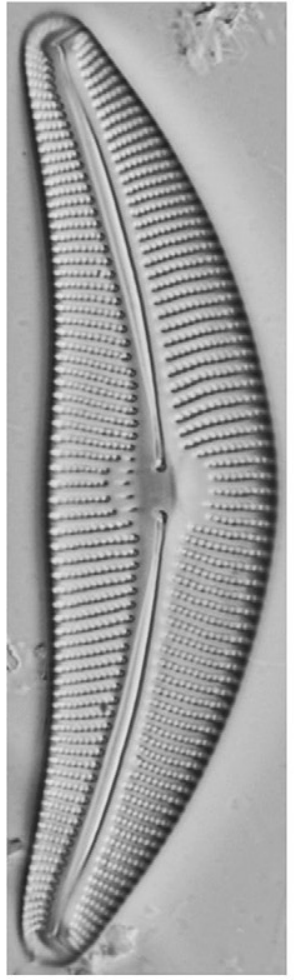

38

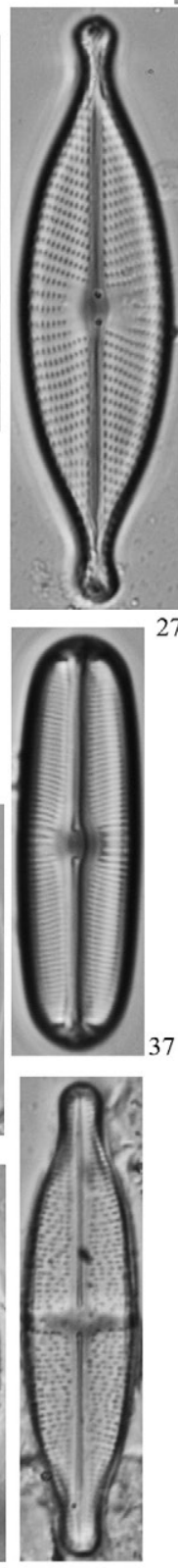

41

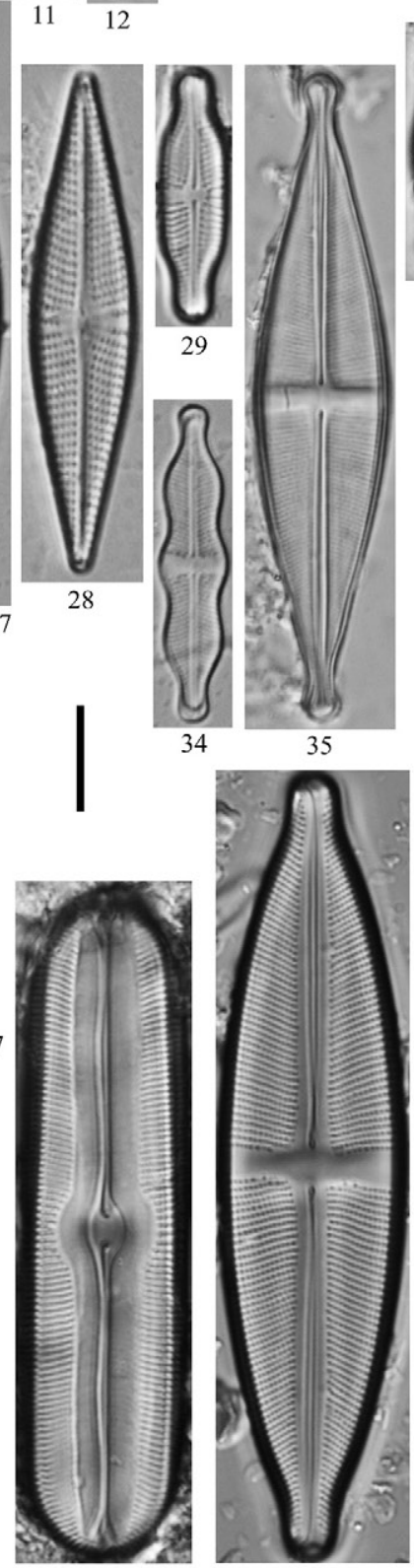

42
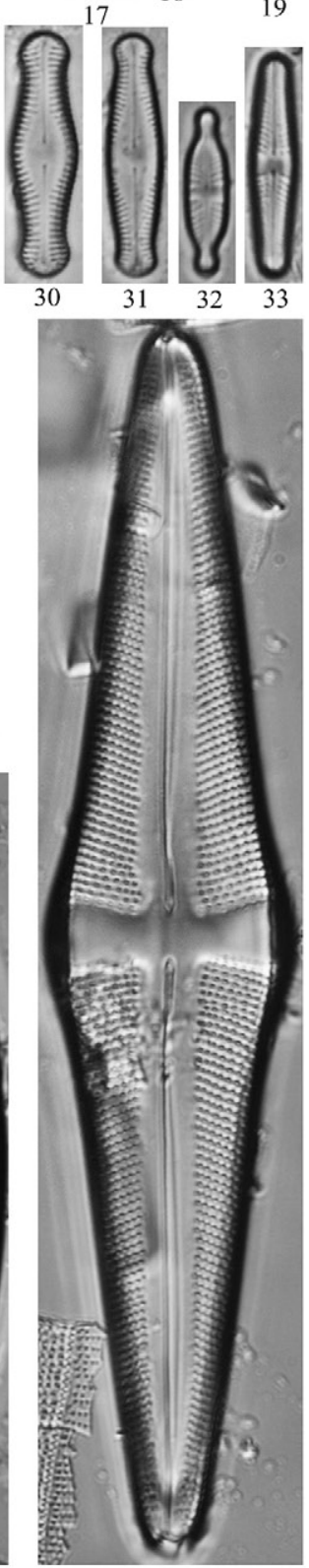

44

Plate 4. LM micrographs of rare and interesting diatoms taxa: 1-2 - Fragilaria brevistriata Grunow, $3-$ F. exigua Grunow, 4 - F. lapponica Grunow, 5 - F. oldenburgiana Hust., 6 - F. virescens Ralfs, 7 - Psammthidium lauenburgianum (Hust.) Bukht. \& Round, 8 - P. subatomoides (Hust.) Bukht. \& Round, 9-10 - Achnanthes exigua (Grunow), 11 - Caloneis fontinalis (Grunow) Lange-Bert. \& Reichardt, 12 - C. lancettula (Schulz-Danzing) Lange-Bert. \& Witkowski, 13-14 - Fallacia subhamulata (Grunow) D.G. Mann, 15-16 - Hippodonta costulata (Grunow) LangeBert., Metzeltin \& Witkowski, 17-18 - Eunotia meisteri Hust., 19 - Luticola acidoclinata Lange-Bert., 20 - Navicula digitoconvergens Lange-Bert., 21 - N. oppugnata Hust., 22 - N. antonii Lange-Bert., $23-N$. reinchardtii (Grunow) Grunow, 24-25 - N. vandamii Schoeman \& Archibald var. vandamii, $26-N$. moskalii Metzeltin, Witkowski \& Lange-Bert., 27 - N. rhynchotella Lange-Bert., 28 - N. trophicatrix Lange-Bert., 29 - Parliberlus protractoides (Hust.) Witkowski, Lange-Bert \& Metzeltin, 30 - Chamaepinnularia krookii (Grunow) Lange-Bert. \& Krammer, 31 - Ch. krookiformis (Krammer) Lange-Bert. \& Krammer, 32 - Stauroneis thermicola (Petersen) Lund, 33 - S. parathermicola Lange-Bert., 34 - S. legumen (Ehrenb.) Kütz., 35 - S. gracilior Reichardt, 36 - Sellaphora pseudopupula (Krasske) Lange-Bert., 37 - S. bacillum (Ehrenb.) D.G. Mann, 38 - Cymbella proxima Reimer, 39 - Amphora hemicycla Stoermer \& Yang, 40 - A. alpestris Levkov, 41 - Stauroneis lauenburgiana Hust., 42 - Sellaphora americana (Ehrenb.) D.G. Mann, 43 - Stauroneis gracilis Ehrenb., 44 - S. acuta W. Smith. Scale bar $10 \mu \mathrm{m}$ 




Plate 5. LM micrographs of rare and interesting diatoms taxa:1-3 - Achnanthidium linearioides (Lange-Bert.) Lange-Bert., 4 - Navicula integra (W. Smith) Ralfs, 5 - N. slesvicensis Grunow, 6-7 - N. kotschyi Grun., 8 - Cymbopleura lata (Grunow) Krammer, 9-10 - Cymbella laevis Nägeli ex Kütz. var. laevis, 11-12 - Navicula bacilloides Hust., 13 - Geissleria decussis (Østrup) Lange-Bert. \& Metzeltin, 14 - Gomphonema sarcophagus Gregory, 15 - Eunotia soleirolii (Kütz.) Rabenh., 16 - Neidium ampliatum (Ehrenb.) Krammer, 17 - N. dubium (Ehenb.) Cleve, 18 - Neidium sp., 19 - Anomoeoneis sphaerophora Pfitzer, 20 - Nitzschia bremensis Hust., 21 - Surirella elegans Ehrenb. Scale bar $10 \mu \mathrm{m}$ 
through agricultural areas which are not cultivated intensively. The waters of these streams have not been subjected to any monitoring studies until now. These studies are the first of this type and allow to determine the ecological status of water which is an important part of the valorization of the environment of the area.

The values of physico-chemical parameters classify the Żołynianka and the Jagielnia waters to I and II quality class (according to the Regulation by the Minister of the Environment dated 9 November 2011 on classification of the uniform parts of surface waters and on environmental quality standards for priority substances).

Average values of electrolytic conductivity in all sampling seasons were below $350 \mu \mathrm{S} / \mathrm{cm}$. This is a typical value for this type of stream, i.e. sandy lowland stream such as the Żołynianka. Water $\mathrm{pH}$ values ranged from 6.5 to 8.2 and slightly exceeded typical values (6-7.5) [Picińska-Fałtynowicz et al. 2007].

The Żołynianka is a small watercourse (about $10 \mathrm{~km}$ ), the Jagielnia is similar (less than $4 \mathrm{~km}$ long), in spite of this both streams were characterized by significant richness of diatom species. 427 diatom taxa were recorded in total in both streams. The Żołynianka is a left-site tributary of the Wisłok River, it was subjected to complex studies of diatomological character. Although the studies were conducted at eight sampling sites located from the spring to the estuary, the number of identified taxa was four hundred and one, and it was lower than in the Żołynianka and the Jagielnia streams [Noga 2012]. Other rivers and streams in the Subcarpathian region were also characterized by lower species richness of diatoms compared to the studied watercourses [Noga, Siry 2010, Tambor, Noga 2011, Bernat, Noga 2012, Pajączek et al. 2012, Noga et al. 2013c,d, Noga et al. 2014a].

Huge diatom species richness in both streams was also confirmed by the value of the ShannonWiener (H') species diversity indicator, which ranged from 4.2 at site four in summer to 7.1 in autumn at site three. Diatoms species richness of the Żołynianka and the Jagielna is comparable to large rivers of the Podkarpackie (for example the Wisłok River). The reason for this may be the fact that along the entire length of the stream there are small fish ponds, which can significantly influence water chemistry. It can be of special importance in a spring section, where the lower trophic waters from the spring mix with the fertile waters of ponds. This specific mixing environment may favor the development of wider group of diatoms compared to the typical streams in the Podkarpacie.

Forty dominant diatom taxa were recorded in both streams. Twenty-seven dominant taxa were found in the Żołynianka and twenty in the Jagielnia. Seven of them were common to both courses: Achnanthidium minutissimum var. minutissimum, Aulacoseira ambigua, Fragilaria capucina var. capucina, Gomphonema parvlum, Navicula gregaria, Nitzschia palea and Planothidium lanceolatum. They are cosmopolitan species, often forming numerous populations in Poland and Europe [Krammer, Lange-Bertalot 1986-1991, Hofmann et al. 2011].

The dominant which occurred numerously in most sampling sites was Navicula gregaria, one of the most frequently recorded species in Central Europe. The tolerance of the species ranges from oligotrophic to $\alpha$-mesotrophic waters. They can occur both in salt and sweet waters. They develop well in oligotrophic waters with high silicate content [Krammer, Lange-Bertalot 1986-1991, Hofmann et al. 2011].

Planothidium lanceolatum was also cosmopolitan species, which frequently occurred in studied watercourses. It occurs both in waters very fertile and poor in nutrients, it abundantly and frequently develops in the streams of the Tatra Mountains. Despite its wide ecological range of tolerance, it avoids acidic water [Krammer, Lange-Bertalot 1086-1991, Kawecka 1996, Hofmann et al. 2011].

At all investigated sampling sites Achnantchidium minutissimum var. minutissimum developed frequently, it is one of the most common species in Central Europe. It occurs in a wide range of pH: from 4.3 to 9.2 and is an indicator species for water rich in oxygen. Ecological optimum is difficult to determine, because it occurs in oligotrophic and rich in nutrients waters. Taxon was frequently recorded in the streams of the Tatra Mountains and Zakopane Basin [Krammer, Lange-Bertalot 19861991, Van Dam et al. 1994, Kawecka 2012].

All taxa discussed above are some of the most common diatoms in most of the rivers and streams in the Podkarpackie. Achnantchidium minutissimum var. minutissimum and Planothidium lanceolatum dominated mainly in the upper part of watercourses, while Navicula gregaria developed frequently in the middle and lower reaches of the studied rivers [Noga, Siry 2010, Tambor, Noga 2011, Noga 2012, Pajączek et al. 2012, Noga et al. 2013c,d, Noga et al. 2014].

Aulacoseira genus, including Aulacoseira ambigua and A. distans were also found among domi- 
nant taxa. All species of the genus Aulacoseira are planktonic forms occurring most frequently in stagnant water reservoirs with high trophy [Krammer, Lange-Bertalot 1986-1991]. The probable reason of occurrence of such a large number of diatoms from genus Aulacoseira in the studied streams was the presence of fish ponds in the spring sections. On the Jagielnia stream during spring season $A u-$ lacoseira ambigua created numerous populations - over a dozen percent of the whole assemblage of diatoms. This took place at the site eight directly behind the Rajszula water reservoir.

In the areas where there was surface runoff from agricultural or pollutant inputs from industry, assemblage dominated by specific diatoms taxa developed, including mainly: Nitzschia palea, Gomphonema parvulum, Amphora pediculus, Navcula radiosa, Melosira varians, Planothidium lanceolatum, Cocconeis placentula, Navicula cryptocephala and Diatoma vulgaris, the appearance of which is indicative of the deterioration of water quality. Nitzschia palea, in particular, can be considered as an indicator of water rich in organic material and nitrogen. It often forms large populations in streams fertilized by urban waste water [Kawecka 1993, Richardson et al. 1996]. Such taxonomic assemblage composition was present at the site four, where most of the above mentioned taxa formed one of the most numerous population. This site was located near residential and commercial buildings and in the short distance from the ponds. Good insolation and no trees along the watercourse enhanced the described phenomenon.

Assessment of ecological status of the studied streams was possible due to the physico-chemical analysis of water and calculation of diatomaceous indices with Omnidia software [Lecointe et al. 1993].

Chemical analysis showed that water at most sites was of very good status. Deviations from standards corresponding to first quality class showed only nitrates, which classify studied waters at the site sixth as below good. Most of the rivers and streams of Podkarpackie (approx. 55\%) also have a very good or good chemical status [WIOŚ 2010].

The results of analyzes carried out with Omnidia software showed moderate or poor ecological status of waters at most sampling sites. The best water quality was at the sites located in the Jagielnia - good or moderate ecological status (II-III quality class). In the Żołynianka stream good ecological status was found only at the site number one in autumn and winter. The values of the analyzed indexes were the worst in the classification at the site four, it frequently demonstrated bad ecological status (V class). TDI index values were most different from the other two (IPS and GDI), always indicating worse quality of water. This is probably the result of the fact that the index does not take the calculation of centric diatoms into account, and it was originally adapted for the waters in the United Kingdom. Diatomaceous indices analysis for Poland showed, that the best indicators to determine the water quality are IPS and GDI indices, and this is why they are recommended for our country [Kawecka et al. 1999, Kelly et al. 2001, Szczepocka, Szulc 2009, Noga et al. 2013b,c,d].

The percentage of species participation characteristic for organic pollution (\%PT) were also calculated, and it was found that only the Jagielnia waters showed no organic pollution. This stream flows in a large part through forest areas and areas not used for agricultural purposes, therefore it contains a small percentage of taxa tolerant to pollution (5.5-17.7\%). In the Żołynianka, definitely the highest PT index values occurred at the site four and five $(>50 \%)$. Such a large percentage of taxa resistant to organic pollution may indicate a risk of eutrophication [Kelly, Whitton 1995]. Slight signs of organic pollution were at the site one and three during spring season.

Diatomaceous analysis with TDI, GDI and IPS indices was also used for assessment of water quality from other watercourses of Podkarpacie: the Baryczka, the Matysówka and the Wisłok [Noga et al. 2013b,c,d]. The waters of the studied streams showed mostly moderate and poor quality (III and IV class), similar to the waters of the Jagielnia and the Żołynianka streams. Also other rivers and streams in Poland were analyzed by diatomaceous indices, and showed similar ecological status [Dumnicka et al. 2006, Szczepocka 2007, Szczepocka, Szulc 2009, Rakowska, Szczepocka 2011].

Sixty diatom taxa were recorded from the Polish Red List of Algae [Siemińska et al. 2006]. Eleven taxa from endangered category (E) and among them, most of the genus Pinnularia [Noga et al. 2014b].

The studied streams are small watercourses flowing through areas used for agriculture, therefore every human activity in catchment can have a decisive impact on the quality of the waters. Significant impact on the studied waters had fish ponds located along the stream (from the spring to the estuary) and the Rajszula reservoir at the Jagielnia which serve as a fish pond. They can contribute to an increase in nutrients and organic matter, and 
The list of diatom taxa recorded in Żołynianka (Z) and Jagielnia (J) in 2009-2011, and endangered category according to Red List of Algae [Siemińska et al. 2006]

\begin{tabular}{|c|}
\hline Achnanthes exigua Grunow $[\mathrm{Z}, \mathrm{J}] \mathrm{R}$ \\
\hline Achnanthidium affine (Grunow) Czarnecki [Z] \\
\hline A. eutrophilum (Lange-Bert.) Lange-Bert. [Z,J] \\
\hline A. linearoides (Lange-Bert.) Lange-Bert. $[\mathrm{J}]$ \\
\hline A. minutissimum var. jackii (Rabenh.) Lange-Bert. [J] \\
\hline A. minutissimum (Kütz.) Czarnecki var. minutissimum [Z,J] \\
\hline A. pyrenaicum (Hust.) Kobayasi [Z,J] \\
\hline A. saprophilum (Kobayasi \& Mayama) Round \& Bukht. [Z] \\
\hline Adlafia brockmannii (Hust.) Bruder \& Hinz [Z,J] \\
\hline Amphora alpestris Levkov [Z,J] \\
\hline A. cimbrica Østrup $[\mathrm{J}] \mathrm{R}$ \\
\hline A. copulata (Kütz.) Schoeman \& Archibald [Z,J] \\
\hline A. hemicycla Stoermer \& Yang $[\mathrm{Z}] \mathrm{R}$ \\
\hline A. inariensis Krammer [Z,J] \\
\hline A. micra Levkov $[Z]$ \\
\hline A. ovalis (Kütz.) Kütz. [Z,J] \\
\hline A. pediculus (Kütz.) Grunow [Z,J] \\
\hline Anomoeoneis sphaerophora Pfitzer $[\mathrm{Z}, \mathrm{J}]$ \\
\hline Asterionella formosa Hassall $[\mathrm{Z}, \mathrm{J}]$ \\
\hline Aulacoseira ambigua (Grunow) Simonsen $[\mathrm{Z}, \mathrm{J}]$ \\
\hline A. distans (Ehrenb.) Simonsen $[\mathrm{Z}, \mathrm{J}]$ \\
\hline A. granulata (Ehrenb.) Simonsen $[\mathrm{Z}, \mathrm{J}]$ \\
\hline A. muzzanensis (Meister) Krammer $[\mathrm{Z}, \mathrm{J}]$ \\
\hline Caloneis amphisbaena (Bory) Cleve [Z] \\
\hline C. bacillum (Grunow) Cleve [Z,J] \\
\hline C. fontinalis (Grunow) Lange-Bert. \& Reichardt [Z,J] R \\
\hline $\begin{array}{l}\text { C. lancettula (Schulz-Danzing) Lange-Bert. \& Witkowski } \\
{[\mathrm{Z}, \mathrm{J}] \mathrm{R}}\end{array}$ \\
\hline C. Ieptosoma (Grunow) Krammer [Z] \\
\hline C. molaris (Grunow) Krammer [Z] R \\
\hline C. silicula (Ehrenb.) Cleve $[\mathrm{Z}, \mathrm{J}]$ \\
\hline C. tenuis (Gregory) Krammer [Z] \\
\hline $\begin{array}{l}\text { Chamaepinnularia krookiformis } \\
\text { (Krammer) Lange-Bert. \& Krammer [J] R }\end{array}$ \\
\hline Ch. krookii (Grunow) Lange-Bert. \& Krammer [Z,J] R \\
\hline Ch. submuscicola (Krasske) Lange-Bert. [Z,J] \\
\hline Cocconeis pediculus Ehrenb. [Z,J] \\
\hline C. placentula var. euglypta Ehrenb. [Z,J] \\
\hline C. placentula var. lineata (Ehrenb.) Van Heurck [Z] \\
\hline C. placentula Ehrenb. var. placentula $[\mathrm{Z}]$ \\
\hline C. pseudolineata (Geitler) Lange-Bert. [Z] \\
\hline Craticula ambigua (Ehrenb.) D.G. Mann $[\mathrm{Z}, \mathrm{J}]$ \\
\hline C. buderi (Hust.) Lange-Bert. [Z,J] \\
\hline C. cuspidata (Kütz.) D.G. Mann [Z,J] \\
\hline C. molestiformis (Hust.) Lange-Bert. [Z,J] \\
\hline Ctenophora pulchella (Ralfs) D.M. Williams \& Round [Z] \\
\hline Cyclostephanos dubius (Hust.) Round [Z,J] \\
\hline
\end{tabular}

C. invisitatus (Hohn \& Hellermann) Theriot, Stoermer \& Håkasson $[\mathrm{Z}, \mathrm{J}]$

Cyclotella atomus Hust. [Z,J]

C. meneghiniana Kütz. [Z,J]

C. planctonica Brunnthaler $[\mathrm{Z}, \mathrm{J}]$

C. cf. glabriuscula (Grunow) Håkansson $[\mathrm{Z}, \mathrm{J}]$

Cymatopleura elliptica (Brébisson) W. Smith [Z,J]

C. solea var. apiculata (W. Smith) Ralfs [Z,J]

C. solea (Brébisson) W. Smith var. solea $[\mathrm{Z}, \mathrm{J}]$

Cymbella aspera (Ehrenb.) Peragallo $[\mathrm{Z}, \mathrm{J}] \mathrm{V}$

C. cistuliformis Krammer $[\mathrm{Z}, \mathrm{J}]$

C. cymbiformis Agardh $[\mathrm{Z}]$

C. excisa Kütz. $[\mathrm{Z}, \mathrm{J}]$

C. hustedtii Krasske var. hustedtii [Z]

C. laevis Nägeli var. laevis $[\mathrm{Z}, \mathrm{J}]$

C. lanceolata (Agardh) Agardh var. lanceolata $[\mathrm{Z}, \mathrm{J}] \mathrm{R}$

C. neocistula Krammer $[\mathrm{Z}, \mathrm{J}]$

C. neocistula var. lunata Krammer $[\mathrm{Z}]$

C. peraspera Krammer [J]

C. proxima Reimer $[\mathrm{Z}] \mathrm{V}$

C. subcistula Krammer [Z,J]

C. tumida (Brébisson) Van Heurck [Z,J]

Cymbopleura anglica (Lagerstedt) Krammer [J]

C. apiculata Krammer [J]

C. cuspidata (Kütz.) Krammer [Z,J]

C. inaequaliformis Krammer [Z,J]

C. inaequalis (Ehrenb.) Krammer [Z,J]

C. lata (Grunow) Krammer [Z,J]

C. naviculiformis (Auerswald) Krammer [Z,J]

C. subaequalis (Grunow) Krammer [Z,J]

Diadesmis contenta (Grunow) D.G. Mann [Z,J]

D. perpusilla (Grunow) D.G. Mann [Z,J]

D. sp. (cf. brekkaensis) (Petersen) D.G. Mann [Z]

Diatoma moniliformis Kütz. [Z]

D. tenuis Agardh $[\mathrm{Z}]$

D. vulgaris Bory $[\mathrm{Z}, \mathrm{J}]$

Diploneis elliptica (Kütz.) Cleve [Z]

D. fontanella Lange-Bert. [Z,J]

D. krammeri Lange-Bert. \& Reichardt [Z,J]

D. oculata (Brébisson) Cleve [Z,J]

D. ovalis (Hilse) Cleve $[\mathrm{Z}] \mathrm{R}$

D. parma Cleve $[\mathrm{Z}] \mathrm{E}$

D. puella (Schumann) Cleve [J]

D. separanda Lange-Bert. [Z,J]

D. subovalis Cleve $[\mathrm{J}]$

Discostella pseudosteligera (Hust.) Houk \& Klee [Z,J]

D. wolterlecki (Hust.) Houk \& Klee [Z] 


\begin{tabular}{|c|}
\hline Discostella cf. pseudosteligera (Hust.) Houk \& Klee [J] \\
\hline Encyonema caespitosum Kütz. var. caespitosum [Z,J] \\
\hline E. neogracile Krammer var. neogracile $[\mathrm{J}]$ \\
\hline E. perpusillum (Cleve) D.G. Mann [Z] \\
\hline E. prostratum (Berkeley) Kütz. [Z] \\
\hline E. reinchardtii (Krammer) D.G. Mann $[\mathrm{Z}]$ \\
\hline E. silesiacum (Bleisch) D.G. Mann [Z,J] \\
\hline E. ventricosum (Agardh) Grunow $[\mathrm{Z}, \mathrm{J}]$ \\
\hline E. vulgare Krammer var. vulgare $[\mathrm{Z}, \mathrm{J}]$ \\
\hline Encyonema sp. [J] \\
\hline Encyonopsis microcephala (Grunow) Krammer [J] \\
\hline Encyonopsis cf. krammeri Reichardt [J] \\
\hline Eolimna minima (Grunow) Lange-Bert. $[\mathrm{Z}, \mathrm{J}]$ \\
\hline $\begin{array}{l}\text { E. subminuscula (Manguin) Moser, Lange-Bert. \& } \\
\text { Metzeltin }[\mathrm{Z}]\end{array}$ \\
\hline Epithemia adnata (Kütz.) Brébisson [Z] \\
\hline E. sorex Kütz. [Z,J] \\
\hline E. turgida (Ehrenb.) Kütz. [Z] \\
\hline Eunotia ambivalens Lange-Bert. \& Tagliaventi [J] \\
\hline E. bilunaris (Ehrenb.) Schaarschmidt $[\mathrm{Z}, \mathrm{J}]$ \\
\hline E. exigua (Brébisson) Rabenh. $[\mathrm{Z}, \mathrm{J}]$ \\
\hline E. formica Ehrenb. [Z] V \\
\hline E. incisa Gregory $[\mathrm{Z}]$ \\
\hline E. meisteri Hust. $[\mathrm{Z}, \mathrm{J}] \mathrm{I}$ \\
\hline E. minor (Kütz.) Grunow $[\mathrm{Z}, \mathrm{J}]$ \\
\hline E. mucophila (Lange-Bert. \& Nörpel) Lange-Bert. [J] \\
\hline E. soleirolii (Kütz.) Rabenh. [J] \\
\hline E. cf. glacialifalsa Lange-Bert. [J] \\
\hline Fallacia egregia (Hust.) D.G. Mann [Z] \\
\hline F. monoculata (Hust.) D.G. Mann [Z] \\
\hline F. pygmaea (Kütz.) Stickle \& D.G. Mann [Z,J] \\
\hline F. subhamulata (Grun.) D.G. Mann [Z] R \\
\hline Fistulifera saprophila (Lange-Bert. \& Bonik) Lange-Bert. [Z] \\
\hline F. bicapitata A. Mayer $[\mathrm{Z}]$ \\
\hline F. brevistriata Grunow $[\mathrm{Z}, \mathrm{J}] \mathrm{R}$ \\
\hline F. capucina Desmazières var. capucina $[\mathrm{Z}, \mathrm{J}]$ \\
\hline F. capucina var. mesolepta (Rabenh.) Rabenh. [Z,J] \\
\hline F. capucina var. vaucheriae (Kütz.) Lange-Bert. [Z,J] \\
\hline F. construens f. binodis (Ehrenb.) Hust. [Z] \\
\hline F. crotonensis Kitton $[\mathrm{Z}, \mathrm{J}]$ \\
\hline F. distans (Grunow) Lange-Bert. [Z] \\
\hline F. famelica (Kütz.) Lange-Bert. [Z] \\
\hline F. gracilis Østrup [Z,J] \\
\hline F. incisa (Boyer) Lange-Bert. [J] \\
\hline F. nanana Lange-Bert. $[\mathrm{Z}, \mathrm{J}] \mathrm{V}$ \\
\hline F. pararumpens Lange-Bert., Hofmann \& Werum $[\mathrm{Z}, \mathrm{J}]$ \\
\hline F. parasitica (W. Smith) Grunow var. parasitica $[\mathrm{Z}, \mathrm{J}]$ \\
\hline F. parasitica var. subconstricta Grunow $[\mathrm{Z}, \mathrm{J}]$ \\
\hline F. perminuta (Grunow) Lange-Bert. $[\mathrm{J}]$ \\
\hline F. pseudoconstruens Marciniak [Z] \\
\hline
\end{tabular}

F. radians (Kütz.) Lange-Bert. [Z,J]

F. tenera (W. Smith) Lange-Bert. [Z] V

Fragilariforma virescens (Ralfs) D.M. Williams \& Round [Z] E

Frustulia vulgaris (Thwaites) De Toni $[\mathrm{Z}, \mathrm{J}]$

Geissleria decussis (Østrup) Lange-Bert. \& Metzeltin [Z,J] R

G. paludosa (Hust.) Lange-Bert. \& Metzeltin [J]

Gomphonema acuminatum Ehrenb. var. acuminatum $[\mathrm{Z}, \mathrm{J}]$

G. affine Kütz. $[\mathrm{Z}] \mathrm{R}$

G. angustum (Kütz.) Rabenh. [Z]

G. angustatum (Kütz.) Rabenh. [Z]

G. augur Ehrenb. [Z]

G. brebissonii Kütz. [J]

G. clevei (Fricke) Gil [J]

G. cymbelliclinum Reichardt \& Lange-Bert. [Z,J]

G. exilissimum (Grunow) Lange-Bert. \& Reichardt [Z,J]

G. gracile Ehrenb. [Z,J]

G. hebridense Gregory $[\mathrm{J}] \mathrm{R}$

G. italicum Kütz. [J]

G. micropus Kütz. [Z,J]

G. minusculum Krasske $[\mathrm{J}]$

G. minutum (Agardh) Agardh [Z,J]

G. olivaceoides Hust. [Z]

G. olivaceum (Hornemann) Brébisson var. olivaceum $[\mathrm{Z}, \mathrm{J}]$

G. pala Reichardt $[\mathrm{J}]$

G. parvulius

(Lange-Bert. \& Reichardt) Lange-Bert. \& Reichardt [Z]

G. parvulum (Kütz.) Kütz. var. parvulum [Z,J]

G. productum (Grunow) Lange-Bert. \& Reichardt [Z,J]

G. pumilum (Grunow) Reichardt \& Lange-Bert. [Z]

G. sarcophagus Gregory $[\mathrm{Z}, \mathrm{J}] \mathrm{V}$

G. subclavatum (Grunow) Grunow $[\mathrm{Z}, \mathrm{J}]$

G. tergestinum (Grunow) M. Schmidt [Z] I

G. truncatum Ehrenb. [Z,J]

G. utae Lange-Bert. \& Reichardt [J]

Grunowia solgensis (Cleve-Euler) M. Aboal [Z,J]

G. tabellaria (Grunow) Rabenh. [Z,J]

Gyrosigma acuminatum (Kütz.) Rabenh. [Z,J]

G. attenuatum (Kütz.) Rabenh. [Z]

G. obtusatum (Sullivant \& Warmley) Boyer [J]

Halamphora montana (Krasske) Levkov [Z]

H. normannii (Rabenh.) Levkov [Z,J]

H. veneta (Kütz.) Levkov $[\mathrm{Z}, \mathrm{J}]$

Hantzschia abundans Lange-Bert. [Z,J]

H. amphioxys (Ehrenb.) Grunow [Z,J]

H. calcifuga Reinchardt \& Lange-Bert. [Z]

Hippodonta capitata

(Ehrenb.) Lange-Bert., Metzeltin \& Witkowski [Z,J]

H. costulata (Grunow) Lange-Bert., Metzeltin \&

Witkowski [J]

Karayevia clevei (Grun.) Bukhtiyarova var. clevei $[\mathrm{J}]$ 


\begin{tabular}{|c|}
\hline K. clevei var. bottnica (Cleve) Bukhtiyarova $[\mathrm{J}]$ \\
\hline Kolbesia ploenensis (Hust.) Kingston [Z] \\
\hline Lemnicola hungarica (Grunow) Round \& Basson $[\mathrm{Z}, \mathrm{J}]$ \\
\hline Luticola acidoclinata Lange-Bert. [Z,J] R \\
\hline L. goeppertiana (Bleisch) D.G. Mann [Z] \\
\hline L. mutica (Kütz.) D.G. Mann $[\mathrm{Z}, \mathrm{J}]$ \\
\hline L. nivalis (Ehrenb.) D.G. Mann [J] \\
\hline L. ventricosa (Kütz.) D.G. Mann [Z] \\
\hline Mayamaea agrestis (Hust.) Lange-Bert. [J] \\
\hline M. atomus (Kütz.) Lange-Bert. var. atomus [Z,J] \\
\hline M. atomus var. alcimonica (Reichardt) Reichardt [Z] \\
\hline M. atomus var. permitis (Hust.) Lange-Bert. [Z,J] \\
\hline M. fossalis (Krasske) Lange-Bert. var. fosslis [Z,J] \\
\hline M. fossaloides (Husdt.) Lange-Bert. [J] \\
\hline Melosira varians Agardh $[\mathrm{Z}, \mathrm{J}]$ \\
\hline Meridion circulare (Gréville) Agardh var. circulare $[\mathrm{Z}, \mathrm{J}]$ \\
\hline M. circulare var. constrictum (Ralfs) Van Heurck [Z,J] \\
\hline Navicula antonii Lange-Bert. [Z,J] \\
\hline N. associata Lange-Bert. [J] \\
\hline N. bacilloides Hust. [Z,J] \\
\hline N. capitatoradiata Germain $[\mathrm{Z}, \mathrm{J}]$ \\
\hline N. cari Ehrenb. [Z,J] \\
\hline N. cincta (Ehrenb.) Ralfs $[\mathrm{Z}, \mathrm{J}]$ \\
\hline N. cryptocephala Kütz. [Z,J] \\
\hline N. cryptotenella Lange-Bert. [Z,J] \\
\hline N. cryptotenelloides Lange-Bert. [Z] \\
\hline N. digitoconvergens Lange-Bert. [Z] \\
\hline N. gregaria Donkin $[\mathrm{Z}, \mathrm{J}]$ \\
\hline N. integra (W. Smith) Ralfs [Z] \\
\hline N. kotschyi Grunow $[\mathrm{Z}, \mathrm{J}]$ \\
\hline N. lanceolata (Agardh) Ehrenb. [Z,J] \\
\hline N. libonensis Schoeman $[\mathrm{Z}, \mathrm{J}]$ \\
\hline N. longicephala Hust. $[\mathrm{Z}, \mathrm{J}]$ \\
\hline N. moskalii Metzeltin, Witkowski \& Lange-Bert. [Z] R \\
\hline N. oblonga (Kütz.) Kütz. [Z] R \\
\hline N. oligotraphenta Lange-Bert. \& Hofmann $[\mathrm{J}] \mathrm{R}$ \\
\hline N. oppugnata Hust. [Z] R \\
\hline N. radiosa Kütz. $[\mathrm{Z}, \mathrm{J}]$ \\
\hline N. recens (Lange-Bert.) Lange-Bert. [Z] \\
\hline N. reichardtiana Lange-Bert. $[\mathrm{Z}, \mathrm{J}]$ \\
\hline N. reinchardtii (Grunow) Grunow [Z] \\
\hline N. rhynchocephala Kütz. [Z,J] \\
\hline N. rhynchotella Lange-Bert. [Z] R \\
\hline N. rostellata Kütz. [Z] \\
\hline N. slesvicensis Grunow $[\mathrm{Z}, \mathrm{J}]$ \\
\hline N. tenelloides Hust. [Z,J] \\
\hline N. tripunctata (O.F. Müller) Bory $[\mathrm{Z}, \mathrm{J}]$ \\
\hline N. trivialis Lange-Bert. $[\mathrm{Z}, \mathrm{J}]$ \\
\hline N. trophicatrix Lange-Bert. [Z,J] \\
\hline
\end{tabular}

N. upsaliensis (Grunow) Peragallo [Z,J]

N. vandamii Schoeman \& Archibald var. vandamii $[\mathrm{Z}, \mathrm{J}]$

$N$. veneta Kütz. $[\mathrm{Z}, \mathrm{J}]$

N. vilaplanii

(Lange-Bert. \& Sabater) Lange-Bert. \& Sabater [Z,J]

N. viridula (Kütz.) Ehrenb. [Z,J]

N. wiesneri Lange-Bert. [J]

Navicula cf. ventralis Krasske [J]

Neidium ampliatum (Ehrenb.) Krammer [Z,J] V

N. affine (Ehrenb.) Pfizer [Z,J]

N. binodeforme Krammer [Z,J]

N. dubium (Ehrenb.) Cleve $[\mathrm{Z}, \mathrm{J}] \mathrm{I}$

N. productum (W. Smith) Cleve $[\mathrm{Z}, \mathrm{J}]$

Neidium cf. cuneatum Krammer \& Metzeltin [J]

Neidium sp. [J]

Nitzschia abbreviata Hust. [Z,J]

N. acicularis (Kütz.) W. Smith $[\mathrm{Z}, \mathrm{J}]$

N. acidoclinata Lange-Bert. [Z,J]

N. acula (Kütz.) Hantzsch [Z,J]

N. amphibia Grunow $[\mathrm{Z}, \mathrm{J}]$

N. angustata (W. Smith) Grunow [Z,J]

N. archibaldii Lange-Bert. [Z]

N. bremensis Hust. [Z]

N. brunoi Lange-Bert. [J]

N. capitellata Hust. $[\mathrm{Z}, \mathrm{J}]$

N. communis Rabenh. [Z,J]

N. dissipata (Kütz.) Grun. ssp. dissipata $[\mathrm{Z}, \mathrm{J}]$

N. dissipata var. media (Hantzsch) Grunow [Z]

$N$. fonticola (Grunow) Grunow [Z,J]

N. frustulum var. inconspicua (Grunow) Grunow [Z,J]

N. gracilis Hantzsch $[\mathrm{Z}, \mathrm{J}]$

N. heufleriana Grunow [Z]

$N$. homburgiensis Lange-Bert. [Z,J]

N. linearis (Agardh) W. Smith $[\mathrm{Z}, \mathrm{J}]$

N. linearis var. tenuis (W. Smith) Grunow $[\mathrm{Z}, \mathrm{J}]$

N. palea (Kütz.) W. Smith [Z,J]

N. paleacea (Grunow) Grunow $[\mathrm{Z}, \mathrm{J}]$

N. perminuta (Grunow) Peragallo $[\mathrm{Z}]$

N. pusilla Grunow $[\mathrm{Z}, \mathrm{J}]$

N. recta Hantzsch $[\mathrm{Z}, \mathrm{J}]$

N. salinarum Grunow $[\mathrm{Z}]$

N. sigma (Kütz.) W. Smith [Z,J]

N. sigmoidea (Nitzsch) W. Smith [Z,J]

N. subacicularis Hust. [Z,J]

N. sublinearis Hust. [Z]

N. supralitorea Lange-Bert. [Z]

N. terrestris (Petersen) Lund $[\mathrm{J}]$

N. trybionella Hantzsch [Z]

$N$. vermicularis (Kütz.) Hantzsch $[\mathrm{Z}, \mathrm{J}]$

Parlibellus crucicula

(W. Smith) Witkowski, Lange-Bert. \& Metzeltin [Z] R 


\begin{tabular}{|c|}
\hline $\begin{array}{l}\text { P. protracta (Grunow) Witkowski, Lange-Bert. \& } \\
\text { Metzeltin [Z] }\end{array}$ \\
\hline $\begin{array}{l}\text { P. protractoides } \\
\text { (Hust.) Witkowski, Lange-Bert \& Metzeltin [Z] R }\end{array}$ \\
\hline Pinnularia acuminata W. Smith [Z] \\
\hline P. anglica Krammer $[\mathrm{J}]$ \\
\hline P. appendiculata (Agardh) Cleve $[\mathrm{Z}, \mathrm{J}]$ \\
\hline P. borealis Ehrenb. var. borealis [Z,J] \\
\hline P. borealis var. sublinearis Krammer $[\mathrm{J}]$ \\
\hline P. brebissonii (Kütz.) Rabenh. [Z,J] \\
\hline P. clevei Patrick [J] \\
\hline P. clevei var. minor (Hust.) Krammer [Z,J] \\
\hline P. esoxiformis Fusey [J] \\
\hline P. fruauenbergiana Reichardt [J] \\
\hline P. gentilis (Donkin) Cleve [Z] \\
\hline P. gibba Ehrenb. $[\mathrm{Z}, \mathrm{J}]$ \\
\hline P. grunowii Krammer [Z,J] \\
\hline P. interruptiformis Krammer [J] \\
\hline P. isselana Krammer [Z,J] \\
\hline P. lundii Hust. [Z,J] \\
\hline P. marchica Schönfelder [Z,J] \\
\hline P. microstauron (Ehrenb.) Cleve $[\mathrm{Z}, \mathrm{J}] \mathrm{V}$ \\
\hline P. microstauron var. angusta Krammer [Z,J] \\
\hline P. neomajor Krammer [Z] \\
\hline P. nobilis (Ehrenb.) Ehrenb. [Z,J] E \\
\hline P. nodosa (Ehrenb.) Ehrenb. [Z,J] E \\
\hline P. nodosa var. robusta (Foged) Krammer [Z,J] \\
\hline P. obscura Krasske $[\mathrm{Z}, \mathrm{J}]$ \\
\hline P. obscuriformis Krammer $[\mathrm{Z}]$ \\
\hline P. oriunda Krammer [Z,J] \\
\hline P. oriundiformis Krammer $[\mathrm{Z}]$ \\
\hline P. perirorrata Krammer [Z] \\
\hline P. rhenohassiaca Krammer \& Lange-Bert. [Z] \\
\hline P. rhombarera var. variarea Krammer [Z] \\
\hline P. rupestris Hantzsch $[\mathrm{J}] \mathrm{E}$ \\
\hline P. schoenfelderi Krammer [Z,J] E \\
\hline P. silvatica Petersen [J] \\
\hline P. sinistra Krammer [Z,J] \\
\hline P. subcapitata Gregory $[\mathrm{Z}]$ \\
\hline P. subcommutata Krammer $[\mathrm{J}]$ \\
\hline P. subcommutata var. nonfasciata Krammer [Z,J] \\
\hline P. subgibba Krammer $[\mathrm{Z}, \mathrm{J}] \mathrm{E}$ \\
\hline P. subgibba var. undulata Krammer $[\mathrm{Z}, \mathrm{J}]$ \\
\hline P. subrupestris Krammer [Z,J] E \\
\hline P. undula (Schumann) Krammer [Z,J] \\
\hline P. viridiformis Krammer $[\mathrm{Z}, \mathrm{J}] \mathrm{E}$ \\
\hline P. viridiformis var. minor Krammer [Z,J] \\
\hline P. viridis (Nitzsch) Ehrenb. $[\mathrm{Z}, \mathrm{J}]$ \\
\hline P. cf. flexuosa Cleve [J] \\
\hline P. cf. irrorata (Grunow) Hust. [J] \\
\hline
\end{tabular}

P. cf. oriundiformis Krammer [Z]

P. cf. parvulissima Krammer [Z]

Placoneis abiskoensis (Hust.) Lange-Bert. \& Metzeltin [Z]

P. anglica (Ralfs) Cox [Z]

P. clementis (Grunow) Cox $[\mathrm{Z}]$

P. constans (Hust.) Cox [Z]

P. dicephala (W. Smith) Mereschkowsky [Z]

P. elginensis (Gregory) Cox [Z]

P. exigua var. signata (Hust.) Hawarth \& Kelly [Z]

P. gastrum (Ehrenb.) Mereschkowsky [Z,J]

P. hambergii (Hust.) K. Bruder $[\mathrm{Z}]$

P. ignorata (Schimanski) Lange-Bert. [J]

P. paraelingensis Lange-Bert. $[\mathrm{Z}, \mathrm{J}]$

P. placentula (Ehrenberg) Heinzerling

P. pseudoanglica (Lange-Bert.) Cox [Z,J]

P. undulata (Østrup) Lange-Bert. [Z,J]

Planothidium frequentissimum (Lange-Bert.)

Lange-Bert. [Z,J]

P. lanceolatum (Brébisson) Lange-Bert. [Z,J]

P. rostratum (Østrup) Lange-Bert. [Z,J]

Platesa conspicua (Mayer) Lange-Bert. [Z,J]

Psammothidium bioretii

(Germain) Bukhtiyarova \& Round [Z,J]

P. lauenburgianum (Hust.) Bukhtiyarova \& Round [Z] V

P. subatomoides (Hust.) Bukhtiyarova \& Round [Z] V

Pseudostaurosira elliptica (Schumann) Edlund, Morales

\& Spaulding [Z]

P. robusta (Fusey) D.M. Williams \& Round [Z] R

Puncticulata radiosa (Grunow) Håkansson [Z,J]

Reimeria sinuata (Gregory) Kociolek \& Stoermer [Z]

Rhoicosphenia abbreviata (Agardh) Lange-Bert. [Z,J]

Rhopalodia gibba Ehrenb. O. Müller var. gibba $[\mathrm{Z}]$

Sellaphora americana (Ehrenb.) D.G. Mann [Z,J] R

S. bacillum (Ehrenb.) D.G. Mann [Z,J] V

S. joubaudii (Germain) Aboal [Z,J]

S. laevissima (Kütz.) D.G. Mann \& Droop [Z,J]

S. mutatoides Lange-Bert. \& Metzeltin [Z]

S. mutata (Krasske) Lange-Bert. [Z]

S. pseudopupula (Krasske) Lange-Bert. [Z,J] E

S. pupula (Kütz.) Mereschkovsky [Z,J]

S. seminulum (Grunow) D.G. Mann [Z,J]

Sellaphora sp. [J]

Simonsenia delognei (Grunow) Lange-Bert. [Z,J]

Stauroforma exiguiformis (Lange-Bert.) Flower, V.J.

Jones \& Round [Z] I

Stauroneis acuta W. Smith $[\mathrm{Z}]$

S. amphicephala Kütz. [J]

S. anceps Ehrenb. [Z,J]

S. borrichii (Petersen) Lund [Z,J]

S. gracilior Reichardt [Z,J]

S. gracilis Ehrenb. $[\mathrm{Z}, \mathrm{J}] \mathrm{V}$ 


\begin{tabular}{|l|}
\hline S. kriegeri Patrick $[\mathrm{Z}, \mathrm{J}]$ \\
\hline S. lauenburgiana Hust. $[\mathrm{Z}]$ \\
\hline S. legumen (Ehrenb.) Kütz. [Z,J] \\
\hline S. optusa Lagerstedt [J] \\
\hline S. parathermicola Lange-Bert. [Z,J] \\
\hline S. phoenicenteron (Nitzsch) Ehrenb. [Z,J] V \\
\hline S. reichardtii Lange-Bert. Cavacini, Tagliaventi \& Alfinito [J] \\
\hline S. separanda Lange-Bert. \& Werum [Z,J] \\
\hline S. smithii Grunow [Z,J] \\
\hline S. subgracilis Lange-Bert. \& Krammer [Z,J] \\
\hline S. tackei (Hust.) Krammer [Z,J] \\
\hline S. thermicola (Petersen) Lund [Z,J] R \\
\hline Stauroneis sp. [J] \\
\hline Staurosira construens Ehrenb. [Z] \\
\hline S. subsalina (Hust.) Lange-Bert. [Z] \\
\hline S. venter (Ehrenb.) Cleve \& Moeller [Z,J] \\
\hline Staurosirella lapponica (Grunow) D.M. Williams \& \\
Round [Z] E \\
\hline S. leptostauron (Ehrenb.) D.M. Williams \& Round [Z] \\
\hline S. oldenburgiana (Hust.) Morales [Z] R \\
\hline S. pinnata (Ehrenb.) D.M. Williams \& Round [Z,J] \\
\hline S. pinnata var. intercendens (Grunow) P.B. Hamilton [Z] \\
\hline Stephanodiscus hantzschii Grunow [Z,J] \\
\hline S. minutulus (Kütz.) Cleve \& Möller [Z,J] \\
\hline
\end{tabular}

\begin{tabular}{|c|}
\hline Surirella angusta Kütz. [Z,J] \\
\hline S. bifrons Ehrenb. [Z,J] V \\
\hline S. biseriata Brébisson $[\mathrm{J}]$ \\
\hline S. brebissonii Krammer \& Lange-Bert. var. brebissonii [Z,J] R \\
\hline S. brebissonii var. kuetzingii Krammer \& Lange-Bert. [Z,J] \\
\hline S. elegans Ehrenb. $[\mathrm{Z}, \mathrm{J}] \mathrm{V}$ \\
\hline S. helvetica Brun $[\mathrm{Z}, \mathrm{J}]$ \\
\hline S. linearis W. Smith $[\mathrm{Z}, \mathrm{J}]$ \\
\hline S. minuta Brébisson $[\mathrm{Z}, \mathrm{J}]$ \\
\hline S. ovalis Brébisson $[\mathrm{Z}]$ \\
\hline S. splendida (Ehrenb.) Kütz. [Z,J] \\
\hline S. terricola Lange-Bert. \& Alles [J] \\
\hline S. visurgis Hust. $[\mathrm{Z}]$ \\
\hline Tabellaria flocculosa (Roth) Kütz. [Z,J] \\
\hline Thallasiosira duostra Pienaar [Z] \\
\hline T. pseudonana Hasle \& Heimdal [Z,J] \\
\hline Trybionella calida (Grunow) D.G. Mann [J] \\
\hline T. debilis Arnott $[\mathrm{Z}, \mathrm{J}]$ \\
\hline T. hungarica (Grunow) Frenguelli [Z,J] \\
\hline T. kuetzingii Alvarez-Blanco \& S. Blanco [Z] \\
\hline UInaria acus (Kütz.) M. Aboal [Z,J] \\
\hline U. biceps (Kütz.) Compère [Z,J] \\
\hline U. capitata (Ehrenb.) Compère [Z] V \\
\hline U. ulna Compère (Nitzsch) [Z,J] \\
\hline
\end{tabular}

$\mathrm{Z}$ - recorded in Żołynianka, $\mathrm{J}$ - recorded in Jagielonia Endangered category: E - endangered, V - vulnerable, R - rare, I - indeterminate

therefore to increase in the fertility of water. It is also very important to preserve ecotone zone, especially in a form of woodlots, which can absorb a significant part of nutrients, even before they reach the watercourse. At the site four, which is below the fish ponds, analyzed parameters showed the worst water quality. This section is completely exposed, regulated and devoid of woodlots along both edges. When the studies were conducted, most of the catchment area had sewage system and only lower section of the stream in Białobrzegi could be affected by waste. Currently, the construction of the sewage system in this part of Białobrzegi village has already been completed [Orlik, Obroślak 2005, Raczyńska, Machula 2006].

\section{REFERENCES}

1. Bernat P., Noga T. 2012. Różnorodność zbiorowisk okrzemek potoku Trzcianka. Rocznik Przemyski 48(3): 29-44.

2. CEMAGREF 1982. Etude des méthodes biologiques quantitative d'appréciation de la qualité des eaux. Rapport Division Qualité des Eaux Lyon
- Agence financiére de Bassin Rhone - Méditerranée - Corse, Pierre - Bénite, pp. 218.

3. Coring E. 1996. Use of diatoms for monitoring acidification in small mountain rivers in Germany with special emphasis on "diatom assemblage type analysis" (DATA). In Use of Algae for Monitoring Rivers II, [In:] B.A. Whitton, E. Rott (eds), Innsbruck, Institut für Botanik, Universität Innsbruck, 7-16 pp.

4. Coste M., Ayphassorho H. 1991. Étude de la qualité des eaux du Bassin Artois-Picardie a l'aide des communautés de diatomées benthiques (Application des indices diatomiques). Raport Cemagref. Bordeaux - Agence de l'Eau Artois-Picardie, Douai, pp. 277.

5. Denys L. 1991. A Check-List of the Diatoms in the Holocene Deposits of the Western Belgian Coastal Plain with a Survey of their Apparent Ecological Requirements. II. Centrales. Ministe`re des Affaires Economiques - Service Ge'ologique de Belgique.

6. Descy J. P., Coste M. 1991. A test of methods for assessing water quality based on diatoms., Verh. int. Ver. Limnol, 24, 2112-2116.

7. Dumnicka E., Jelonek M., Kwandrans J., Wojtal A., Żurek R. 2006. Ichtiofauna i status ekologiczny wód Wisły, Raby, Dunajca i Wisłoki. Institute of 
Nature Conservation, Polish Academy of Sciences, Kraków, pp. 220.

8. Hofmann G., Werum M., Lange-Bertalot H. 2011. Diatomeen im Süßwasser - Benthos vom Mitteleuropa. Bestimmungsflora Kieselalgen für die ökologische Praxis. Über 700 der häufigsten Arten und ihre Ökologie. [In:] H. Lange-Bertalot. (ed.), A.R.G. Gantner Verlag K.G., pp. 908.

9. Kawecka B. 1993. Zbiorowiska glonów osiadłych w potokach Kotliny Zakopiańskiej. [In:] Z. Mirek, H. Piekoś-Mirkowa (eds) Przyroda Kotliny Zakopiańskiej. Tatry i Pdtatrze 2. Kraków-Zakopane, 209-217 pp.

10. Kawecka B. 1996. Glony. [In:] Z. Mirek, Z. Głowacki, K. Klimek, H. Piękoś-Mirkowa (eds), Przyroda Tatrzańskiego Parku Narodowego. Tatry i Podtatrze. T. 3. Zakopane - Kraków, pp. 347-361.

11. Kawecka B. 2012. Diatom diversity in streams of the Tatra National Park (Poland) as indicator of environmental conditions. W. Szafer Institute of Botany, Polish Academy of Sciences, Kraków, pp. 213.

12. Kawecka B., Eloranta P.V. 1994. Zarys ekologii wód słodkich i środowisk lądowych. PWN, Warszawa.

13. Kawecka B., Sanecki J. 2003. Didymosphenia geminata in running waters of southern Poland symptoms of change in water quality? Hydrobiol. 495, 193-201.

14. Kawecka B., Kwandrans J., Szyjkowski A. 1999. Use of algae for monitoring rivers in Poland - Situation and development. [In:] Use of algae for monitoring rivers III. J. Prygiel, B.A. Whitton, J. Bukowska (eds), Agence de l'Eau Artois-Picardie, pp. 57-65.

15. Kelly M.G., Whitton B.A. 1995. The Trophic Diatom Index: a new index for monitoring eutrophication in rivers. J. Appl. Phycol. 7, 433-444.

16. Kelly M.G., Adams C., Graves A.C., Jamieson J., Krokowski J., Lycett E.B., Murray-Bligh J., Pritchard S., Wilkins C. 2001. The Trophic Diatom Index: A User's Manual. Revised Edition. Environment Agency, Bristol, BS32 4UD, pp. 1-74.

17. Kondracki J. 2009. Geografia regionalna Polski. PWN, Warszawa.

18. Krammer K. 2000. The genus Pinnularia. Vol. 1. [In:] H. Lange-Bertalot (ed) Diatoms of Europe. A.R.G. Gantner Verlag K.G., pp. 703.

19. Krammer K. 2002. Cymbella. [In:] Diatoms of Europe 3. H. Lange-Bertalot (ed.), A.R.G., Gantner Verlag K.G., Rugell, pp. 584.

20. Krammer K. 2003. Cymbopleura, Delicata, Navicymbula, Gomphocymbellopsis, Afrocymbella. [In:] Diatoms of Europe 4. H. Lange-Bertalot (ed.), A.R.G., Gantner Verlag K.G., Rugell., pp. 530.

21. Krammer K., Lange-Bertalot H. 1986-1991. Bacillariophyceae. 1-4. [In:] H. Ettl, J. Gerloff, H.
Heyning., D. Mollenhauer (eds), Süsswasserflora von Mitteleuropa 2(1-4). G. Fischer Verlag, Stuttgart - New York - Jena.

22. Kwandrans J., Eloranta P., Kawecka B., Wojtan K. 1998. Use of benthic diatom communities to evaluate water quality in rivers of southern Poland. Journal of Applied. Phycology, 10, 193-201.

23. Lach J., Wnuk Z. 1998. Środowisko przyrodnicze gminy Żołyni. [In:] W. Bonusiak (ed.) Dzieje Żołyni. Wyd. Mitel, Rzeszów, 41-80.

24. Lange-Bertalot H. 1993. 83 New taxa and much more than 100 taxonomic clarifications supplementary to Süßwasserflora von Mitteleuropa. Vol. 2/1-4. J. Cramer, Berlin - Stuttgart.

25. Lange-Bertalot H. 2001. Navicula sensu stricto. 10 genera separated from Navicula sensu lato. Frustulia. [In:] H. Lange-Bertalot (ed.) Diatoms of Europe. A.R.G. Gantner Verlag K.G., pp. 526.

26. Lecointe C., Coste M., Prygiel J. 1993. OMNIDIA: software for taxonomy, calculation of diatom indices and inventories management. Hydrobiol. 269/270, 509-513.

27. Levkov Z. Amphora sensu lato. 2009. [In:] H. Lange-Bertalot (ed.) Diatoms of Europe. Koeltz Scientific Books, Köningstein/Germany, pp. 916.

28. Michalczyk Z. 1988. Komentarz do Mapy Hydrograficznej w skali 1:50 000, arkusz 156.4 - Łańcut, Wyd. OPGK, Rzeszów.

29. Noga T. 2012. Diversity of diatom communities in the Wisłok River (SE Poland). Phycological Reports: Current advances in algal taxonomy and its applications: phylogenetic, ecological and applied perspective. Institute of Botany Polish Academy of Sciences, Krakow, pp. 109-128.

30. Noga T., Siry K. 2010. Różnorodność flory okrzemek w potoku Łubienka (Pogórze Dynowskie, Polska SE). Zeszyty naukowe PTIE i PTG 12, 75-86.

31. Noga T., Stanek-Tarkowska J., Kocielska-Streb M., Ligęzka R., Kloc U., Peszek Ł. 2012. Endangered and rare species of diatoms in running and standing waters on the territory of Rzeszów and the surrounding area [In:] Practical Applications of Environmental Research. Nauka dla Gospodarki. nr 3/2012, J. Kostecka, J. Kaniuczak (eds.), 331-340.

32. Noga T., Stanek-Tarkowska J., Pajączek A., Peszek Ł. 2013a. New records of Geissleria declivis (Hust.) Lange-Bert. (Bacillariophyceae) in Europe, the first in Poland. Oceanological and Hydrobiological Studies 42(4), 480-485.

33. Noga T., Stanek-Tarkowska, Pajączek A., Peszek Ł., Kochman N. 2013b. Ecological characteristics the diatoms of river Wisłok using their role of indicators for assessing water quality. Journal of Ecological Engeneering 14(3), 18-27.

34. Noga T., Stanek-Tarkowska J., Peszek Ł., Pajączek A., Kowalska S. 2013c. Use of diatoms to asses 
water quality of anthropogenically modified Matysówka stream. Journal of Ecological Engineering 14(2), 1-11.

35. Noga T., Stanek-Tarkowska J., Kochman N., Peszek Ł., Pajączek A., Woźniak K. 2013d. Application of diatoms to assess the quality of the waters of the Baryczka stream, left-side tributary of the river San. Journal of Ecological Engineering 14 (4), 8-23.

36. Noga T., Kochman N., Peszek Ł., Stanek-Tarkowska J., Pajączek A. 2014a. Diatoms (Bacillariophyceae) in rivers and streams and on cultivated soils of the Podkarpacie Region in the years 2007-2011. Journal of Ecological Engineering 15(1), 6-25.

37. Noga T., Peszek Ł., Stanek-Tarkowska J., Pajączek A. 2014b. The Pinnularia genus in south-eastern Poland with consideration of rare and new taxa to Poland. Oceanological and Hydrobiological Studies 43(1), 77-99.

38. Orlik T., Obroślak R. 2005. Analiza jakości wód w stawie rybnym w zlewni rzeki Giełczwi. Acta Agrophysica, 5(3), 705-710.

39. Pajączek A., Musiałek M., Pelczar J., Noga T. 2012. Diversity of diatoms in the Mleczka River, Morwawa River and Różanka Stream (tributaries of the Wisłok River, SE Poland), with particular reference to threatened species - Phycological Reports: Current advances in algal taxonomy and its applications: phylogenetic, ecological and applied perspective. Institute of Botany Polish Academy of Sciences, Krakow, pp. 129-152.

40. Picińska-Fałtynowicz J., Błachuta J., Kotowicz J., Mazurek M., Rawa W. 2007. Wybór typów jednolitych części wód rzecznych i jeziornych do oceny stanu ekologicznego na podstawie fitobentosu wraz z rekomendacją metodyki poboru i analizy prób. Główny Inspektorat Ochrony Środowiska, 1-29 pp.

41. Prygiel J., Coste M. 1993. The assessment of water quality in the Artois-Picardie water basin (France) by the use of diatom indices. Hydrobiol: 269/279, 343-349.

42. Prygiel J, Coste M. 1999. Progress in the use of diatoms for monitoring rivers in France. [In:] J. Prygiel, B. A. Whitton, J. Bukowska, (eds). Use of Algae for Monitoring Rivers III. Agence de l'Eau Artois-Picardie, Douai, 165-179.

43. Prygiel J., Coste M., Bukowska J. 1998. Review of the major diatom-based techniques for the quality assessment of continental surface waters [In:] J. Prygiel, B.A Whitton, J. Bukowska (eds), Use of algae for monitoring rivers, Agence de l'Eau Artois-Picardie, Douai, France, 224-238.

44. Raczyńska M., Machula S. 2006. Oddziaływanie stawów karpiowych na jakość wód rzeki Krąpiel (Pomorze Zachodnie). [In:] Infrastruktura i ekologia terenów wiejskich. PAN, Komisja Technicznej Infrastruktury Wsi, 4(2), 141-149.
45. Rakowska B., Szczepocka E. 2011. Demonstration of the Bzura River restoration using diatom indices. Biologia 66(3), 411-417.

46. Richardson J.L., Mody N.S., Stacey, M.E. 1996. Diatoms and water quality in Lancaster County (PA) streams: a 45-year perspective. Pennsylvania Acad. Sci., 70, 30-39.

47. Rozporządzenie Ministra Środowiska z dnia 9 listopada 2011 r. w sprawie sposobu klasyfikacji stanu jednolitych części wód powierzchniowych oraz środowiskowych norm jakości dla substancji priorytetowych, Dz.U. 2011 nr 257 poz. 1545, 15059-15097.

48. Rumrich U., Lange-Bertalot H., Rumrich M. 2000. Diatomeen der Anden. Von Venezuela bis Patagonien/Feuerland. [In:] H. Lange-Bertalot (ed.) Iconographia Diatomologica, Vol. 9. A.R.G. Gantner Verlag K.G., Königstein-Germany, 1-673 pp.

49. Siemińska J., Bąk M., Dziedzic J., Gąbka M., Gregorowicz P., Mrozińska T., Pełechaty M., Owsiany P. M., Pliński M., Witkowski A. 2006. Red list of the algae in Poland - Czerwona lista glonów w Polsce. [In:] Z. Mirek et al. (eds) Red list of plants and fungi in Poland - Czerwona lista roślin i grzybów Polski. Polish Academy of Sciences, Kraków, 35-52 pp.

50. Stoermer E. F., Smol J. P. 2004. The Diatoms: Application for the Environmental and Earth Sciences. Cambridge University Press, Cambridge, 3-40 pp.

51. Stoermer E. F., Smol J. P. 2010. The Diatoms: Application for the Environmental and Earth Sciences. Second edition. Cambridge University Press, Cambridge, 3-98 pp.

52. Szczepocka E. 2007. Benthic diatoms from the outlet section of the Bzura River 30 years ago and presently. Oceanol. Hydrobiol. St. 36(1), 255-260.

53. Szczepocka E., Szulc B. 2009. The use of benthic diatoms in estimating water quality of variously polluted rivers. Oceanol. Hydrobiol. St. 38(1), 17-26.

54. Tambor A., Noga T. 2011. Różnorodność flory okrzemek w rzece Lubcza i potoku Lubenia (Podgórze Rzeszowskie, Polska SE). Rocznik Przemyski, 47(3), 105-118.

55. Van Dam H., Martens A., Sinkeldam J. 1994. A coded checklist and ecological indicator Values of freshwater diatoms from the Netherlands. Netherlands J. Aquatic Ecol. 28, 117-133.

56. Werum M., Lange-Bertalot H. 2004. Diatoms in Springs from Central Europe and elsewhere under the influence of hydrogeology and anthropogenic impacts. A.R.G. Gantner Verlag K.G., Germany, pp. 418.

57. Whitton B. A., Rott E. 1996. Use of algae for monitoring rivers II. [In:] E. Rott (ed.) Publisher, Institut für Botanik, Universität Innsbruck, Innsbruck, Austria.

58. WIOŚ. 2010. Raport o stanie środowiska w województwie podkarpackim w 2010 roku. 